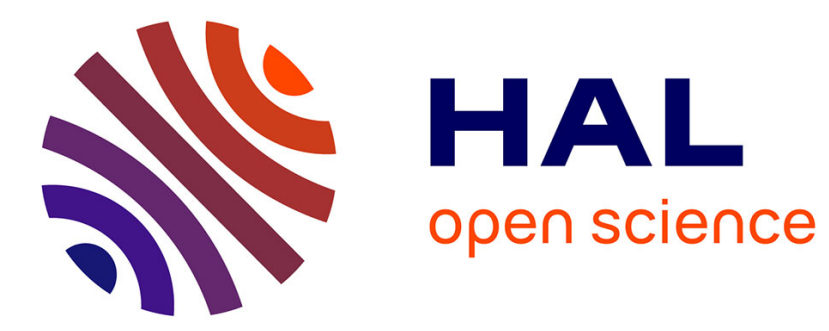

\title{
Exploring options for managing strategies for pea-barley intercropping using a modeling approach
}

Marie Launay, Nadine N. Brisson, Sylvain Satger, H. Hauggaard-Nielsen, G. Corre-Hellou, E. Kasynova, R. Ruske, E.S. Jensen, M.J. Gooding

\section{To cite this version:}

Marie Launay, Nadine N. Brisson, Sylvain Satger, H. Hauggaard-Nielsen, G. Corre-Hellou, et al.. Exploring options for managing strategies for pea-barley intercropping using a modeling approach. European Journal of Agronomy, 2009, 31 (2), pp.85-98. 10.1016/j.eja.2009.04.002 . hal-02665735

\section{HAL Id: hal-02665735 https://hal.inrae.fr/hal-02665735}

Submitted on 31 May 2020

HAL is a multi-disciplinary open access archive for the deposit and dissemination of scientific research documents, whether they are published or not. The documents may come from teaching and research institutions in France or abroad, or from public or private research centers.
L'archive ouverte pluridisciplinaire HAL, est destinée au dépôt et à la diffusion de documents scientifiques de niveau recherche, publiés ou non, émanant des établissements d'enseignement et de recherche français ou étrangers, des laboratoires publics ou privés. 


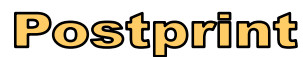

Version définitive du manuscrit publié dans / Final version of the manuscript published in : European Journal of Agronomy, 2009, vol.31, no.2, 85-98, DOI: 10.1016/j.eja.2009.04.002

\section{Exploring options for managing strategies for pea-barley intercropping using a modeling} approach.

M. Launay ${ }^{{ }^{*}}$, N. Brisson ${ }^{1}$, S. Satger ${ }^{1}$, H. Hauggaard-Nielsen ${ }^{2}$, G. Corre-Hellou ${ }^{3}$, E. Kasynova ${ }^{4}$, R. Ruske $^{4}$, E.S. Jensen ${ }^{2}$, M.J. Gooding ${ }^{4}$.

${ }^{1}$ Unité Agroclim, INRA, Site Agroparc, 84914 Avignon Cedex 9, France

${ }^{2}$ Risø National Laboratory, DK-4000 Roskilde, Denmark

${ }^{3}$ Ecole Supérieure d'Agriculture, F-49007 Angers, France

${ }^{4}$ Department of Agriculture, The University of Reading, RG6 1AR, UK

* To whom all correspondence should be addressed:

Tel.: +33(0)4 32722367 fax: +33(0)4 32722362

E-mail address: Marie.Launay@avignon.inra.fr 


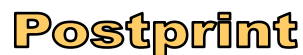

Version définitive du manuscrit publié dans / Final version of the manuscript published in : European Journal of Agronomy, 2009, vol.31, no.2, 85-98, DOI: 10.1016/j.eja.2009.04.002

Abstract - A modeling study was carried out into pea-barley intercropping in northern Europe. The two objectives were (a) to compare pea-barley intercropping to sole cropping in terms of grain and nitrogen yield amounts and stability, and (b) to explore options for managing pea-barley intercropping systems in order to maximize the biomass produced and the grain and nitrogen yields according to the

5 available resources, such as light, water and nitrogen. The study consisted of simulations taking into account soil and weather variability among three sites located in northern European countries (Denmark, United Kingdom and France), and using 10 years of weather records. A preliminary stage evaluated the STICS intercrop model's ability to predict grain and nitrogen yields of the two species, using a 2-year dataset from trials conducted at the three sites. The work was carried out in two phases, 10 (a) the model was run to investigate the potentialities of intercrops as compared to sole crops, and (b) the model was run to explore options for managing pea-barley intercropping, asking the following three questions: i) in order to increase light capture, would it be worth delaying the sowing dates of one species? ii) how to manage sowing density and seed proportion of each species in the intercrop to improve total grain yield and $\mathrm{N}$ use efficiency? iii) how to optimize the use of nitrogen resources by 15 choosing the most suitable preceding crop and/or the most appropriate soil? It was found that (1) intercropping made better use of environmental resources as regards yield amount and stability than sole cropping, with a noticeable site effect, (2) pea growth in intercrops was strongly linked to soil moisture, and barley yield was determined by nitrogen uptake and light interception due to its height relative to pea, (3) sowing barley before pea led to a relative grain yield reduction averaged over all 20 three sites, but sowing strategy must be adapted to the location, being dependent on temperature and thus latitude, (4) density and species proportions had a small effect on total grain yield, underlining the interspecific offset in the use of environmental growth resources which led to similar total grain yields whatever the pea-barley design, and (5) long-term strategies including mineralization management through organic residue supply and rotation management were very valuable, always favoring intercrop total grain yield and $\mathrm{N}$ accumulation.

Keywords: crop model, intercrop, Pisum sativum, Hordeum vulgare, yield, nitrogen. 


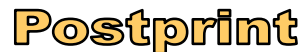

Version définitive du manuscrit publié dans / Final version of the manuscript published in : European Journal of Agronomy, 2009, vol.31, no.2, 85-98, DOI: 10.1016/j.eja.2009.04.002

\section{Introduction}

Low input agriculture, including organic farming, offers new challenges to agronomy. The objective is to use cropping strategies with limited use of external inputs able to maintain the production level while increasing the product quality and decreasing the environmental risks. Intercropping can be a

5 good subject for such strategies. It is defined as the agricultural practice of cultivating two or more crops in the same space at the same time (Andrews and Kassam, 1976). Compared to sole cropping, intercropping has been reported to improve the utilization of available resources and increase the level and stability of yield (Willey, 1979; Ofori and Stern, 1987, Vandermeer, 1989), and is commonly used in the tropics (Altieri, 1991). Available resources, such as light, water and nutrients are used more 10 efficiently by the intercrop as a result of complementary use by the intercrop components for growth factors (Snaydon and Satorre, 1989; Hauggaard-Nielsen et al., 2001 a, b). For example, grain legumecereal intercrops, and especially pea-barley intercrops (Pisum sativum L. - Hordeum vulgare L.), have been shown to optimize nitrogen use because barley is more competitive for soil mineral $\mathrm{N}$ than pea thanks to its faster-growing and deeper roots, while pea is forced to increase its reliance on symbiotic

$15 \quad \mathrm{~N}_{2}$ fixation (Jensen, 1996; Hauggard-Nielsen et al., 2001b; Bellostas et al., 2003; Corre-Hellou and Crozat, 2004, Zhang et al., 2004). However field experiments may lead to contradictory results (Pridham and Entz, 2008), being strongly dependent on the environmental conditions in which they were done, so that they cannot be extrapolated to other sites. Their results may be difficult to interpret because of the various interacting factors (Szumigalski and Van Acker, 2008). For these reasons, a modeling approach was attempted in the INTERCROP FP5 EU project (a cost-shared project cofunded by the European Community) in order to improve understanding of interspecific interactions and to help manage intercropping. This project particularly focused on cereal-legume intercrops that were cultivated and harvested simultaneously in order to increase protein concentration in the mixed harvested grains. A modeling study was carried out into pea-barley intercropping, taking into account soil and weather variability over three sites in northern Europe (Denmark, United Kingdom and France) and using 10 years of weather records, with the following objectives: (a) to compare peabarley intercropping to sole cropping in terms of grain and nitrogen yield amounts and stability, and (b) to explore options for managing pea-barley intercropping systems in order to maximize the 


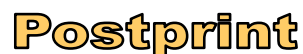

Version définitive du manuscrit publié dans / Final version of the manuscript published in : European Journal of Agronomy, 2009, vol.31, no.2, 85-98, DOI: 10.1016/j.eja.2009.04.002

biomass produced and the grain and nitrogen yields according to the available resources. The environmental resources considered were light, water and nitrogen. Biotic stresses were not taken into account, and the selected model was the intercrop version of the STICS model (Brisson et al., 2004) which had been previously adapted and evaluated on independent experimental datasets of pea-barley 5 conventional intercrops in Angers (Corre-Hellou, 2005).

Using the model to explore options for managing pea-barley intercropping firstly required evaluating its reliability in the environmental conditions of the simulations (Lamanda et al., 2008). For this reason, a preliminary stage of our study aimed at evaluating the model's ability to simulate the key variables, namely those indicating the cropping system performance for light interception, nitrogen 10 accumulation and grain production, with reasonable accuracy. This evaluation was done from experiments conducted in Denmark, United Kingdom and France as part of the INTERCROP project. We then did virtual experiments using 10 years' weather data from the French, English and Danish sites, in two phases. First, the model was run to investigate the potentialities of intercrops as compared to sole crops, in order to (a) improve understanding of interspecific interactions and (b) reveal the 15 limiting factors of such systems in the simulated conditions. Secondly, based on these results, management strategies were selected according to their feasibility for farmers, and tested by means of simulations, answering the following questions: i) in order to increase light capture, would it be worth delaying the sowing dates of the quickly emerging species? ii) how to use basic management tools like sowing density and seed proportion of each species in the intercrop to improve total grain yield and $\mathrm{N}$ use efficiency? iii) how to optimize the use of nitrogen resources by choosing the most suitable preceding crop and/or the most appropriate soil? 


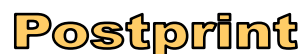

Version définitive du manuscrit publié dans / Final version of the manuscript published in : European Journal of Agronomy,

2009, vol.31, no.2, 85-98, DOI: 10.1016/j.eja.2009.04.002

\section{Materials and methods}

\subsection{Data description and evaluation}

\section{$\underline{\text { Sites, soils and climates: }}$}

Within the framework of the INTERCROP project, experiments were carried out in 2003 and 2004 in

5 Tåstrup (Denmark, $55^{\circ} 40^{\prime} \mathrm{N}, 12^{\circ} 18^{\prime} \mathrm{E}$ ), Reading (England, $51^{\circ} 45^{\prime} \mathrm{N}, 0^{\circ} 93^{\prime} \mathrm{W}$ ) and Thorigné (France, $\left.47^{\circ} 37^{\prime} \mathrm{N}, 0^{\circ} 39^{\prime} \mathrm{O}\right)$ on spring pea and spring barley grown as sole crops (SC) and pea-barley intercrops (IC). The climate is oceanic at all the three sites, with average annual rainfall of 550-650 $\mathrm{mm}$ and a narrow annual range of temperatures. Weather conditions during the experimental period are shown in Fig. 1. The French site (FR) had the driest climate $(142 \mathrm{~mm}$ and $115 \mathrm{~mm}$ of cumulative rainfall 10 during the crop growing period in 2003 and 2004 respectively) and a particularly high evaporative demand in 2003. The cumulative solar radiation from emergence to harvest was the lowest at the English site (UK) with $187 \cdot 10^{3} \mathrm{~J} \cdot \mathrm{cm}^{-2}$ in 2003 and $177 \cdot 10^{3} \mathrm{~J} \cdot \mathrm{cm}^{-2}$ in 2004 , compared with values of $195-205 \cdot 10^{3} \mathrm{~J} \cdot \mathrm{cm}^{-2}$ at the French and Danish (DK) sites. Meteorological data were collected by weather stations located less than $1 \mathrm{~km}$ from the field trials.

15 The soil characteristics of the three sites are given in Table 1. Soils at Danish and English sites were loamy sands ( $12 \%$ clay, $25 \%$ silt, $63 \%$ sand and $8-9 \%$ clay, $18-19 \%$ silt and $72-74 \%$ sand respectively) whereas at the French site the soil was a sandy clayey loam (13-17\% clay, $44-51 \%$ silt, $36-39 \%$ sand). Soils had high available water content in the $0-150 \mathrm{~cm}$ layer (216 to $162 \mathrm{~mm}$ according to the soils), while organic matter contents within the ploughed layer differed considerably between 20 the low-organic English site soils $(0.11 \%$ of organic nitrogen in the top $25 \mathrm{~cm})$ and the high-organic French site soils $(0.2 \%$ of organic nitrogen in top $25 \mathrm{~cm})$. The agricultural history of all sites was two years of grass-clover mixtures followed by a winter or spring monocotyledon as the preceding crop: winter wheat (Triticum aestivum L.) in DK, ryegrass which was totally incorporated (Lolium multiflorum L.) in FR, forage maize (Zea mays_L.) in 2003 in UK, and oat (Avena sativa L.) in 2004 in

25 UK. All these preceding crops were also grown following organic farming recommendations, and the previous crop's straw was incorporated before sowing. At none of the sites had grain legumes been grown for the preceding 6 years, and weed infestation was moderate.

\section{Experimental design}

Comment citer ce document : 


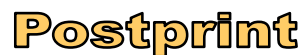

Version définitive du manuscrit publié dans / Final version of the manuscript published in : European Journal of Agronomy, 2009, vol.31, no.2, 85-98, DOI: 10.1016/j.eja.2009.04.002

The same experimental layouts and field and laboratory methods were used at all sites according to a carefully planned protocol. As a compromise, pea cv. Baccara and barley cv. Scarlett were chosen as the most suitable cultivars for grain production at all sites. The experimental plots $(3 \mathrm{~m} \times 10 \mathrm{~m})$, consisting of 4 treatments, were laid out in a randomized block design with four replicates. Two intercrop treatments were tested: one with $100 \%$ pea $+50 \%$ barley (additive design, P100B50) and the other with $50 \%$ pea $+50 \%$ barley (replacement design, where half the recommended density level for sole pea crop was applied considering that barley would "replace" pea density, P50B50), the percentages referring to the sowing density of the two SCs. For pea SC plant densities ranged from 90 to 115 plants $\cdot \mathrm{m}^{-2}$ and for barley SC they ranged from 300 to 440 plants $\cdot \mathrm{m}^{-2}$ depending on year and site. 10 In the intercrop designs, pea and barley were sown simultaneously in alternating single rows, with an inter-row distance of 0.12 to $0.15 \mathrm{~m}$ according to the local sowing equipment. Sowing dates, growth durations, and sowing densities are given in Table 2. The two crops were sown and harvested on the same dates at a given site. The harvest date was driven by barley maturity which was later than pea maturity. At all sites crops were managed according to organic farming practices without any

15 pesticides or manufactured fertilizers. No organic matter was applied; only the previous crop's straw was incorporated before sowing. Mechanical weeding was done before sowing only and no irrigation was applied.

\section{$\underline{\text { Sampling and analytical methods: }}$}

Five key development stages were recorded: i) emergence, ii) pea 6-leaf (stage 106 according to 20 Knott, 1987), iii) pea beginning of flowering (stage 203 according to Knott, 1987), iv) barley ear emergence (stage 55 according to Tottman, 1987), and v) physiological maturity of both crops. Plant height of the two crop species was measured at these five stages. At least two samplings were carried out during the experimental period, one at the beginning of flowering of peas (around 10 days before barley ear emergence) and one at pea maturity (from two days to two weeks before barley maturity, 25 depending on site and year). Sampling consisted of cutting the plants just above the soil surface on a 6 row $\mathrm{x} 1 \mathrm{~m}$ area, and separating the sample into pea, barley and weed fractions. Aerial dry matter of pea and barley plants was measured after $48 \mathrm{~h}$ drying at $70^{\circ} \mathrm{C}$ in a well-ventilated oven. Dry grain yield, total and grain $\mathrm{N}$ contents, as well as the amount of $\mathrm{N}_{2}$ fixed by peas, were measured at harvest. The 


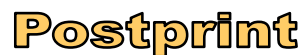

Version définitive du manuscrit publié dans / Final version of the manuscript published in : European Journal of Agronomy, 2009, vol.31, no.2, 85-98, DOI: 10.1016/j.eja.2009.04.002

total and grain $\mathrm{N}$ concentrations were measured using Dumas' method (Dumas, 1981). The nitrogen yield was calculated as the product of grain yield and $\% \mathrm{~N}$ content in the grain. The ${ }^{15} \mathrm{~N}:{ }^{14} \mathrm{~N}$ ratio of pea samples was determined by mass spectrometry. The amount of $\mathrm{N}_{2}$ fixed was calculated as the product of pea biomass, $\% \mathrm{~N}$ content and the proportion of plant $\mathrm{N}$ derived from $\mathrm{N}_{2}$ fixation (Corre-Hellou et 5 al., 2006). The percentage of plant $\mathrm{N}$ derived from $\mathrm{N}_{2}$ fixation $(\% \mathrm{Ndfa})$ was determined by the ${ }^{15} \mathrm{~N}$ natural abundance method (Amarger et al., 1979) using barley SC as reference crop for calculating $\mathrm{N}_{2}$ fixation in pea SC and pea IC.

$\% \mathrm{Ndfa}=100 \mathrm{x}\left(\left(\delta^{15} \mathrm{~N}\right.\right.$ pea $-\delta^{15} \mathrm{~N}$ barley $) /\left(\beta\right.$ fix $-\delta^{15} \mathrm{~N}$ barley $\left.)\right)$ where $\beta$ fix $(-1$ for pea) (Mariotti et al., 1980 ) is the isotopic fraction factor associated with $\mathrm{N}_{2}$ fixation processes. Total $\mathrm{N}$ use efficiency 10 (NUE) was calculated as the ratio of the final pea+barley crop dry weight to the pea+barley intercrop's $\mathrm{N}$ accumulation (both measured at harvest). Soil mineral $\mathrm{N}$ and water content were measured at sowing in order to initialize their soil status in the model. Weed pressure was observed during crop growth and remained low.

\section{2.2. Model}

Since the selected model is run to improve understanding of interspecific interactions and to help manage intercropping, a mechanistic modeling approach was required which takes account of cultural practices. Three approaches are possible when modeling intercropping. The first is an extension of sole crop modeling, assuming the system to be composed of two species instead of one. In such models, concentrating on the dynamics of the system, modules were added to the initial sole crop model in order to take into account the sharing of light and nutrients between species (Kiniry et al., 1992, Caldwell et al., 1993, Berntsen et al., 2004, Tsubo et al., 2005). The second relies on a description of the intercrop as a series of discrete crop-based points, with flow of mass and energy between each. This spatially discretized approach allows one to account for large spatial variations, and the field response results from a spatially integrated calculation (Huth et al., 2002). The last approach derives from architecture modeling, emphasizing a realistic description of the 3D structure of the complex two-species canopy, which leads to fine-scale descriptions of processes at the organ level (Sonohat et al., 2002). In addition to their heavy cost in terms of calculation time, the last two 


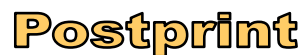

Version définitive du manuscrit publié dans / Final version of the manuscript published in : European Journal of Agronomy, 2009, vol.31, no.2, 85-98, DOI: 10.1016/j.eja.2009.04.002

approaches involve fewer factors and processes influencing the growing cycle, sometimes focusing on one aspect of competition at the expense of others (Wu et al., 2005, Karray et al., 2008). Therefore, since the environmental resources were limited to light, water and nitrogen, the intercrop version of the STICS crop model (Brisson et al., 2004), corresponding to the first approach, was selected. The model is known for its adaptability to various crops, its robustness resulting from parameterizations done under various soil and weather conditions, and its plasticity, relying on options of formalisms for both physiology and management (Brisson et al., 2009).

The STICS growth model simulates crop growth and development, as well as water and $\mathrm{N}$ balance, using a daily time step. Water and $\mathrm{N}$ stress are taken into account through indices that can reduce leaf 10 growth, root growth and biomass accumulation under water- and nutrient-limited growing conditions. $\mathrm{N}_{2}$ fixation is calculated from above-ground growth and then reduced by the effects of limiting factors such as nitrate availability and water content (Corre-Hellou et al., 2007).

The adaptation of STICS's conceptual basis and formalizations to intercropping relies first on a simplified definition of the complex agronomic system of intercropping, and secondly on the 15 adaptation of the modules calculating resource capture (light, water and nitrogen). The soil-plantatmosphere system was divided into three sub-systems within the canopy: the uppermost canopy and two layers of understorey canopy, a shaded part and a sunlit part, each being defined by a light microclimate. These light microclimates, estimated from a radiation balance (Brisson et al., 2004), drive the different behavior of the sub-systems in terms of growth (dry matter accumulation, leaf area 20 growth) and water and nitrogen budgets (transpiration, nitrogen uptake, stress index). The estimation of the water requirements for both crops relies on light partitioning coupled to a resistive scheme (Shuttleworth and Wallace, 1985; Wallace, 1995) and applied on a daily time step (Brisson et al., 1998). The phasic development is considered the same for both parts of the understorey. Also the soil environment is assumed to be the same for both crops: i.e. the horizontal differentiation within the soil profile is neglected in favor of the vertical one. It is assumed that the interactions between the two root systems result from the influence of the soil on each crop root profile through its penetrability and water dynamics. 


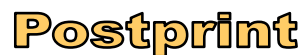

Version définitive du manuscrit publié dans / Final version of the manuscript published in : European Journal of Agronomy, 2009, vol.31, no.2, 85-98, DOI: 10.1016/j.eja.2009.04.002

Specific modules or options were added to the earlier sole crop version (Brisson et al., 2003) in order to take account of the ecophysiological features of these complex systems. They concern radiation interception, an energy budget driving water requirements and microclimate, and dynamics of the root system as influenced by soil status. Those modules and options are briefly described below.

$5 \quad$ Radiation intercepted by the two crops:

The model estimates the fraction of the radiation intercepted by the uppermost canopy and the fraction transmitted to both components of the understorey canopy. The elementary unit for calculation consists of the half-width of the uppermost foliage (the other half-width belonging to the contiguous pixel), the shaded surface of the understorey crop and the sunlit surface of the understorey canopy.

10 The fraction of absorbed photosynthetically active radiation (FAPAR) of both crops depends greatly on their respective heights, which not only depend on the plant characteristics but also on the growth conditions. In order to allow inversion of dominance of the two crops, the intercrop plant status (dominant or understorey) is a function of the respective plant heights, which can change several times throughout the growing cycle as a function of the growth rates of each crop.

15 Energy budget and microclimate:

In the model, the energy budget is used to estimate the crop water requirement through the "resistive scheme" which consists of estimating plant water requirements and soil evaporation using the Shuttleworth and Wallace daily time-step model (Brisson et al., 1998). This approach is particularly suitable for intercrops, because it allows for microclimatic effects on water requirements: convection

20 beneath the dominant canopy and decrease in the vapor pressure deficit due to transpiration from the understorey plants. Then actual soil evaporation and plant transpiration are calculated independently by means of a soil water balance. These fluxes are then re-introduced into the energy budget to calculate crop temperature, which is a driving variable for growth and development of the plant.

Leaf growth of the understorey crop:

25 In the STICS crop model, temperature is the main variable explaining potential leaf growth according to the crop's development stage, unlike some other models where the increase in the leaf surface area is derived from their increase in mass by means of the specific leaf area. In the case of sole crops, the robustness of this formalism relies on a strong correlation between intercepted radiation (driving the 


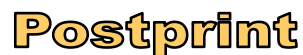

Version définitive du manuscrit publié dans / Final version of the manuscript published in : European Journal of Agronomy,

2009, vol.31, no.2, 85-98, DOI: 10.1016/j.eja.2009.04.002

biomass accumulation by means of photosynthesis) and temperature (driving leaf area increase by means of phasic development). Therefore, this correlation implicitly links the LAI and biomass accumulation processes and makes the separate calculation of LAI and biomass accumulation realistic. In the case of an understorey crop, this correlation no longer exists because of the shade of the 5 dominant crop. It is therefore important to limit leaf expansion when not enough structural biomass is available to expand leaves at the rate predicted by temperature and also to account for light quality effects. This is done (Brisson et al., 2004) by means of :

- a trophic limitation on leaf expansion, using the notion of the maximum leaf expansion allowed per unit of biomass accumulated in the plant,

- the calculation of an equivalent plant density for the understorey crop which accounts for the presence of the dominant crop; this empirical relationship allows the inter-plant competition to be increased compared to the sole crop situation.

Root profiles:

The model does not consider allelopathy but it assumes that for intercrops the influence of the crop 15 root systems on each other results from the influence of the soil status on the root distribution. Growth in root length is first calculated, and then distributed to each layer of the soil profile. It is calculated using a logistic function that is analogous to that of leaves: a first calculation of the root length growth rate describes a logistic curve. This value is then multiplied by the effective crop temperature, the plant density combined with an inter-plant competition factor that is characteristic for the variety, and

20 the water logging stress index. The new root length is then distributed in each layer of the soil profile in proportion to the roots present and as a function of the soil constraints. Each constraint is defined at the layer level, and is assumed to be independent of the others: soil dryness, taking account of the plant's sensitivity to this effect, soil compaction through bulk density and waterlogging, which contributes to the root distribution in the layers with high mineral nitrogen content.

25 After a lifetime which depends on the species, the roots senesce and enter the mineralization process as crop residue at the end of the crop cycle.

The parameters of the different modules of the STICS model were calibrated for pea and barley using data from literature and results obtained in pea and barley SCs (Corre-Hellou, 2005). The model was 


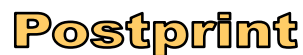

Version définitive du manuscrit publié dans / Final version of the manuscript published in : European Journal of Agronomy,

2009, vol.31, no.2, 85-98, DOI: 10.1016/j.eja.2009.04.002

then evaluated on pea-barley intercrops cultivated in conventional farming conditions, and the simulated responses of the intercrops were in agreement with the observations from the experimental datasets (Corre-Hellou et al., 2007).

\section{2.3. Dataset for the model experiment}

Weather records for 11 years in France and UK (1994-2004) and 9 years for Denmark were used for the numerical experiment (Figure 2). Cumulative solar radiation is on average $50 \mathrm{~J} \cdot \mathrm{cm}^{-2}$ greater by the end of the growth cycle (end of July) in the Danish and French sites than in the English site (300 $\mathrm{J} \cdot \mathrm{cm}^{-2}$ compared to $250 \mathrm{~J} \cdot \mathrm{cm}^{-2}$ ). The Danish site appeared to receive the most rain in spring and

10 summer while the French site received the most in winter, and the English site had the most uniform distribution of rainfall over the year. Daily temperatures were similar during the growth cycle between the Danish and English sites, while it was warmer at the French one.

The simulation protocol depended on the objective:

(a) Pea-barley IC/SC comparison in terms of grain and nitrogen yield amounts and stability: the

15 simulation design mimicked the experimental design from the INTERCROP project (pea SC, barley SC, additive pea-barley IC and replacement pea-barley IC) with the same recommended sowing densities (90 and 300 plants $\mathrm{m}^{-2}$ for pea and barley SCs, respectively), the same sowing dates as in 2004 (Table 2), and neither irrigation nor mineral fertilization according to organic farming practices.

(b) Option exploration for managing pea-barley intercropping systems in order to maximize the

20 biomass produced and the grain and nitrogen yields according to the available resources:

i) Delay in sowing dates: 2 weeks' delay between pea and barley sowing for both density treatments (additive and replacement designs) were simulated. The first sowing date was set 2 weeks ahead of the reference date given in Table 2. No relay-intercropping was considered in order to conform to the INTERCROP FP5 EU project framework, and therefore to maintain the two crops' simultaneous

25 harvest.

ii) Management of sowing densities in the IC: to find the optimum density and species proportions in the IC, we relied on Hauggaard-Nielsen et al.'s (2006) experimental work. They tested two combinations with $(1 / 3)$ pea $+(2 / 3)$ barley $(\mathrm{Bp})$ and $(2 / 3)$ pea $+(1 / 3)$ barley $(\mathrm{Pb})$ at three different 


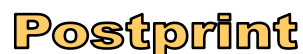

Version définitive du manuscrit publié dans / Final version of the manuscript published in : European Journal of Agronomy, 2009, vol.31, no.2, 85-98, DOI: 10.1016/j.eja.2009.04.002

densities. The first level was the recommended density of the two SCs (90 and 300 plants $\mathrm{m}^{-2}$ for pea and barley, respectively), the second was half, and the third was double. The two combinations (Bp and $\mathrm{Pb}$ ) were factorially combined with the three density levels (low, recommended and high). Barley and pea densities were 400 and 60 plants $\mathrm{m}^{-2}$ respectively for the Bp combination and 200 and 120

5 plants $\mathrm{m}^{-2}$ for the $\mathrm{Pb}$ combination, at the high density level. They were 200 and 30 plants $\mathrm{m}^{-2}$, and 100 and 60 plants $\mathrm{m}^{-2}$ for the $\mathrm{Bp}$ and $\mathrm{Pb}$ combinations respectively, at the recommended density level, and 100 and 15 plants $\mathrm{m}^{-2}$, and 50 and 30 plants $\mathrm{m}^{-2}$ for the $\mathrm{Bp}$ and $\mathrm{Pb}$ combinations respectively, at the low density level. Simulation results at the three sites, in terms of yield and $\mathrm{N}$ use efficiency, were examined at three stages: (d1) at the beginning of barley stem elongation (stage 30 according to 10 Tottman, 1987), (d2) at barley booting (stage 45 according to Tottman, 1987), and (d3) pea maturity (stage 209 according to Knott, 1987).

iii) Test of soil nitrogen availability: the agronomic design mimicked the additive and replacement pea-barley IC of the INTERCROP experimental design, using two hypotheses of soil nitrogen availability factorially combined to give 4 combinations:

- $20 \%$ increase in the soil organic nitrogen content at the beginning of the trial, compared to the actual one of field trials.

- two various initial mineral nitrogen profiles at sowing (in the $2 \mathrm{~m}$ soil profile) supposed to account for two types of preceding crop ( a $3 \mathrm{~g} \mathrm{~N} \cdot \mathrm{m}^{-2}$ total with $1 \mathrm{~g} \mathrm{~N} \cdot \mathrm{m}^{-2}$ in the first $0-30 \mathrm{~cm}$ layer and $2 \mathrm{~g} \mathrm{~N} \cdot \mathrm{m}^{-2}$ in the second layer corresponding to an N-demanding preceding crop like seed rape, or a $15 \mathrm{~g} \mathrm{~N} \cdot \mathrm{m}^{-2}$ total with $2 \mathrm{~g} \mathrm{~N} \cdot \mathrm{m}^{-2}$ in the first layer, $7 \mathrm{~g} \mathrm{~N} \cdot \mathrm{m}^{-2}$ in the second layer and $6 \mathrm{~g} \mathrm{~N} \cdot \mathrm{m}^{-2}$ in the third layer corresponding to a less demanding crop like maize for example).

The first hypothesis leads to a variable release of mineral nitrogen throughout the growing cycle through mineralization, while the second tests the capacity of the cropping system to capture mineral nitrogen present at the beginning of growth in competition with leaching. 


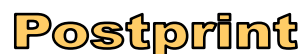

Version définitive du manuscrit publié dans / Final version of the manuscript published in : European Journal of Agronomy, 2009, vol.31, no.2, 85-98, DOI: 10.1016/j.eja.2009.04.002

\subsection{Evaluation of the results}

In order to evaluate the model, simulated key variables (plant height, plant nitrogen content, aboveground dry matter, yield, soil mineral nitrogen content), were compared to the corresponding measured variables using two criteria:

5 1) The mean difference between simulated $\hat{y}_{\mathrm{i}}$ and measured $\mathrm{y}_{\mathrm{i}}: M D=1 / n \sum_{i=1}^{n}\left(\hat{y}_{i}-y_{i}\right)$, where $n$ is the number of replicates. $M D$ indicates the under- or over-estimate.

2) The root mean square error (RMSE): RMSE $=\left(1 / n \sum\left(y_{i}-\hat{y}_{i}\right)^{2}\right)^{1 / 2}$

The land equivalent ratio (LER), often used to evaluate the competitiveness of intercropping, was calculated for yield (Willey, 1979) and plant nitrogen content (Kwabiah, 2004 and Szumigalski et al.,

10 2006). It is defined as the relative land area (or growth resources) required when growing SC to produce the yield achieved in IC (Willey, 1979). LER for a barley-pea IC is the sum of the partial LER values (De Wit and Van den Bergh, 1965) for barley $\left(\mathrm{L}_{\mathrm{B}}\right)$ and pea $\left(\mathrm{L}_{\mathrm{P}}\right)$.

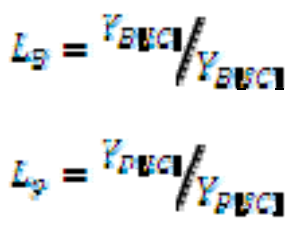

15

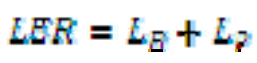

Where $\mathrm{Y}_{\mathrm{B}[\mathrm{IC}]}$ and $\mathrm{Y}_{\mathrm{P}[\mathrm{IC}]}$ are the yields (or plant nitrogen contents) of barley and pea in IC, respectively, and $\mathrm{Y}_{\mathrm{B}[\mathrm{SC}]}$ and $\mathrm{Y}_{\mathrm{P}[\mathrm{SC}]}$ the yields (or plant nitrogen contents) of barley and pea in SC, respectively. LER greater than one indicates that IC improves the use of environmental resources for plant growth compared to SC. When LER is less than one, resources are used more efficiently by SC than by IC.

20 Analysis of variance were carried out, using the AOV procedure of the S-PLUS software (S-PLUS, 2001). The significance of differences between treatments was estimated using F-tests at $\mathrm{P}<0.01$ and $\mathrm{P}<0.05$. 


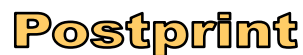

Version définitive du manuscrit publié dans / Final version of the manuscript published in : European Journal of Agronomy,

2009, vol.31, no.2, 85-98, DOI: 10.1016/j.eja.2009.04.002

\section{Results and Discussion}

\subsection{Evaluation of the model performances}

Before using the model to explore, compare and study the feasibility of agronomic strategies in intercropping we must evaluate its ability to simulate the variables of interest with reasonable

5 precision. We chose key variables that indicate the cropping system's capability for light interception which is correlated to the relative height of the two components of the canopy (crop height), nitrogen accumulation (plant $\mathrm{N}$ content) through root absorption (soil mineral nitrogen content) and $\mathrm{N}_{2}$ fixation, biomass and grain production (above-ground dry matter and grain yield). This evaluation was performed on the French, British and Danish sites of the INTERCROP experimental network for all 10 the treatments. It was found (Fig. 3) that the model succeeds in reproducing the two species' competitiveness for light through the «plant height » variable (RMSE $=0.14 \mathrm{~m}, \mathrm{MD}=-0.05 \mathrm{~m}$ ), and for nitrogen accumulation through the "plant $\mathrm{N}$ content" variable (RMSE $=2.7 \mathrm{~g} \mathrm{~N} \cdot \mathrm{m}^{-2}, \mathrm{MD}=-0.6 \mathrm{~g} \mathrm{~N} \cdot \mathrm{m}^{-2}$ ) and the soil mineral nitrogen content $\left(\mathrm{RMSE}=2.6 \mathrm{~g} \mathrm{~N} \cdot \mathrm{m}^{-2}, \mathrm{MD}=0.6 \mathrm{~g} \mathrm{~N} \cdot \mathrm{m}^{-2}\right.$ ) (Fig. $3 \mathrm{a}, 3 \mathrm{~b}$ and $\left.3 \mathrm{e}\right)$. Crop height is correctly simulated whatever the treatment (SC or IC), which is of a great importance when 15 simulating radiation interception and microclimate in intercropping. Low levels of plant nitrogen, typical of organic farming, are also simulated correctly without bias, corroborating soil mineral nitrogen content simulations (Fig. 3e). They differ from levels encountered in conventional farming (e.g. Pea N content at maturity was around $15 \mathrm{~g} \mathrm{~N} \cdot \mathrm{m}^{-2}$ in Fig. $3 \mathrm{~b}$ whereas it was measured between 25 and $30 \mathrm{~g} \mathrm{~N} \cdot \mathrm{m}^{-2}$ in the conventional trials in Angers described by Corre-Hellou (2005). Pea plant $\mathrm{N}$

20 comes from $\mathrm{N}_{2}$ fixation and $\mathrm{N}$ uptake, so our results confirm the model's ability to correctly estimate $\mathrm{N}_{2}$ fixation as demonstrated by Corre-Hellou (2005). These results show that the model can be used to test the species competitiveness for light and nitrogen in intercropping conditions.

As far as total above-ground dry matter and grain yield are concerned (Fig.3c and 3d), the model calculations are without bias whatever the treatment, and have acceptable error (RMSE $=151 \mathrm{~g} \cdot \mathrm{m}^{-2}$, $25 \mathrm{MD}=-12 \mathrm{~g} \cdot \mathrm{m}^{-2}$ for above-ground dry matter, and $\mathrm{RMSE}=74 \mathrm{~g} \cdot \mathrm{m}^{-2}, \mathrm{MD}=7 \mathrm{~g} \cdot \mathrm{m}^{-2}$ for grain yield) considering no biotic stresses are taken into account. The only badly simulated yield value is for the French additive design in 2003, where the large overestimate could be attributed to powdery mildew 


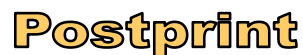

Version définitive du manuscrit publié dans / Final version of the manuscript published in : European Journal of Agronomy, 2009, vol.31, no.2, 85-98, DOI: 10.1016/j.eja.2009.04.002

damage. This highlights the limitations of the present model assumptions (Brisson et al., 2004) for simulating organic farming, often characterized by severe biotic stresses.

The balance between pea and barley contributions to the total grain yield was better simulated for the replacement than for the additive design, as shown in Fig. 4a. However, the respective advantages of

5 ICs over SCs, quantified by LER values of more or less than 1, were properly reproduced (Fig 4b). Simulated grain yield LER values were close to the measured ones and similar to the ones obtained in previous studies (Kwabiah, 2004, Chen et al., 2004). The values for total above-ground dry matter and plant $\mathrm{N}$ content were slightly underestimated, particularly for plant $\mathrm{N}$ content, because of the underestimation of pea LER values. Though measured values of barley plant N LER were higher than 10 analogous values for grain yield, the model failed to reproduce this tendency. It indicates that barley IC used more nitrogen per g of grain produced than barley SC, as already shown in cotton-wheat IC by Zhang et al., 2008. However, we need to be cautious with these results since the differences between measured and simulated total LERs were of the same order of magnitude in additive and replacement designs.

15 To sum up this evaluation phase, the results have shown that the model:

- provides the key variables to simulate the inter-species competition and production of both species with sufficient precision;

- reproduces the advantage of IC over SC, especially for total above-ground dry matter and grain yield, although it slightly underestimates it for plant $\mathrm{N}$ content;

20 - provides similar bias-free results whatever the treatment and the IC design (additive or replacement).

\subsection{Use of the model to compare pea-barley intercropping to sole cropping}

When investigating the potentialities of intercrops as compared to sole crops, or later on when exploring options for managing strategies for pea-barley intercropping, the question of which biophysical variables to examine is important but, whatever they are (grain or nitrogen yields of the crop for animal feeding or grain processing), it is important: i) to look at relative values to be able to judge the positive or negative effect of a technical option and ii) to examine different locations and 


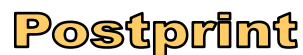

Version définitive du manuscrit publié dans / Final version of the manuscript published in : European Journal of Agronomy, 2009, vol.31, no.2, 85-98, DOI: 10.1016/j.eja.2009.04.002

seasons to be sure of robust results. We hope that the use of 10 years' weather records and three European sites will lend support to our results. All the results presented in this chapter and the following one (§3.3) are simulated ones.

5 Therefore, the model was first run to investigate the potential of pea-barley IC as compared to the corresponding SC as regards grain and nitrogen yield amounts and stability.

In spite of half the pea density, the replacement IC design exhibited no difference in grain yield (Fig. 5) with the additive IC design, as observed previously in the experimental results. It illustrates the good competitive ability of pea when mixed with barley, especially in Denmark where pea's 10 contribution to total IC grain yield was greater than in other sites.

Since all the LERs, calculated for yield as well as plant N, are above one (Table 3), the advantage of IC over SC is clear. Despite the lack of yield difference between the two IC designs, an advantage in terms of LER appears for the additive version in Denmark, while for the other sites the two IC designs are equivalent. If we compare the three locations, the French one is the least promising. As plant $\mathrm{N}$

15 LER may be underestimated, making our simulated results slightly pessimistic, this study proves how valuable intercropping can be to make optimal use of environmental growth resources.

Two multi-factor analysis of variance were carried out on the Total grain yield LER: the first one used year variations as replicates to establish the explanatory factors among site, design (additive and replacement), Pea grain yield and Barley grain yield, and the second one used site $\mathrm{x}$ design variations as replicates in order to establish the explanatory factors among year, Pea grain yield and Barley grain yield. Only Pea grain yield significantly affected Total grain yield LER $\left(\mathrm{p}=4.43 \cdot 10^{-5}\right.$ and $\mathrm{p}=9.8 \cdot 10^{-6}$ respectively for the two analysis of variance), denoting that whatever the weather (year factor), soil (site factor), or design, and whatever the barley competitiveness, the intercrop advantage over sole crops depends, in our simulated conditions, on the success of pea yield elaboration in the mixture.

25 Consequently, the model was used later on to identify the driving and limiting factors that influence pea grain yield elaboration.

Stability of IC production as compared to SC was evaluated by the coefficient of variation (CV) of the simulated grain yield (Table 4). Pea grain yield is less stable in ICs than in SCs at all the sites. 


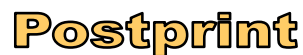

Version définitive du manuscrit publié dans / Final version of the manuscript published in : European Journal of Agronomy, 2009, vol.31, no.2, 85-98, DOI: 10.1016/j.eja.2009.04.002

Conversely, barley grain yield stability depends on the site: in UK and France, IC gives more stable grain yields than SCs, while in Denmark the reverse is true. As regards the total IC grain yields, the site effect is large and the benefit of IC is greater in England and Denmark.

5 In order to better understand the way that competition between species influences grain yield we looked at intermediate simulated variables that could help to identify limiting factors. The two IC designs gave similar results and are presented together (Fig. 6).

First, pea grain yield variability was shown to relate to $\mathrm{N}_{2}$ fixation, itself limited by the water stress index (the lower the index the greater the stress) as shown in Fig. 6a and 6b. Second, barley grain yield

10 variability was explained by the nitrogen stress index in Fig. 6c (the lower the index the greater the stress), which depends to a large extent on rooting (presented in Fig. 6d at ear emergence as a total value for the whole profile). This result must be related to the low levels of nitrogen supply in this simulation context, mimicking organic farming and thus emphasizing nitrogen stress. The respective pea/barley yields in the ICs vary a lot depending on the site: in Denmark and UK, barley is less 15 productive than in France. This difference in competitiveness can be explained by the relative heights of the two species: in France in 2004 (Fig 6e), barley emerged earlier than peas and remained taller during the whole of crop growth, enabling it to intercept light better. In contrast, in Denmark and UK barley emerged slightly after pea, which maintained its advantage for the whole crop cycle in Denmark (Fig 6f), while in UK barley outgrew peas later on in growth. Over all the simulations, pea 20 emergence occurred 3 days before, 1 day before, and 3 days after barley emergence at the French, English and Danish sites respectively. The model distinguishes two phases in emergence, germination which is achieved when the growing degree-days from planting in the seed bed reaches a specific phenological threshold $\left(50^{\circ} \mathrm{C} \cdot \mathrm{d}\right.$ for barley and $60^{\circ} \mathrm{C} \cdot \mathrm{d}$ for pea), and shoot elongation. whose rate is assumed to be a logistic function of soil degree-days, that may slow down with unsuitable soil moisture. Barley parameters such as germination and shoot elongation should be faster than for pea, involving an earlier emergence. But barley sensitivity to soil dryness was parameterized as being greater than for pea, which introduced an emergence delay at the Danish site. Indeed, sowing date being delayed in Denmark (mid-April compared to mid-March in the French and English sites) 


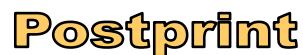

Version définitive du manuscrit publié dans / Final version of the manuscript published in : European Journal of Agronomy, 2009, vol.31, no.2, 85-98, DOI: 10.1016/j.eja.2009.04.002

because of the low temperatures, the sowing-emergence period occurred when evaporative demand was greater because of higher solar radiation (mean daily Potential Evapotranspiration was $2.83 \mathrm{~mm}$ at the Danish site compared to $1.83 \mathrm{~mm}$ and 1.41 for the French and English sites respectively), involving soil dryness through evaporation (cumulated actual soil evaporation was $40 \mathrm{~mm}$ compared to $20 \mathrm{~mm}$ at the French and English sites during the sowing-emergence period). Moreover, the delay in emergence significantly affected barley height $\left(\mathrm{p}=3.1 \cdot 10^{-7}\right)$ over sites, years and designs, and therefore played a big part in barley yield elaboration, as shown on Fig. $6 \mathrm{~g}$ where points are site-specific.

In short, the model run under low levels of nitrogen supply proved the value of intercropping to make best use of environmental resources as regards total grain and nitrogen yields and indicated a site 10 effect as regards grain yield stability, but total IC yield can be more stable over years than each of the SC yields. The model did not indicate differences between additive and replacement IC designs. It identified factors explaining the competitiveness of the two species: pea growth appears to be strongly linked to soil moisture through nodosity activity, and barley yield was determined by nitrogen uptake through rooting and by light interception due to its height relative to pea, arising from the emergence 15 delay between the two species.

\subsection{Use of the model to explore options for managing pea-barley intercropping systems}

\section{i) In order to increase light capture, would it be worth delaying the sowing dates of the quick-emerging} species?

As we had found that the relative growth of the two species is site-dependent, we simulated early sowing for barley compared to pea, early sowing for pea compared to barley, and simultaneous sowing for both species. In order to calculate LER (Table 5), SCs were also simulated, using the same sowing date as the corresponding crop in the IC design.

25 Delaying the sowing date did not significantly affect the IC total grain yield and had little influence on total grain yield Land Equivalent Ratio (LER). Indeed, as expected, sowing barley before pea significantly increased $(\mathrm{p}<0.01)$ barley grain yield by $30 \%$ in additive and replacement designs, but did not increase the total grain yield (only a 4\% [not significant] increase was observed over all sites 


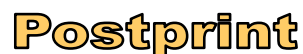

Version définitive du manuscrit publié dans / Final version of the manuscript published in : European Journal of Agronomy, 2009, vol.31, no.2, 85-98, DOI: 10.1016/j.eja.2009.04.002

for the replacement design). This result was accentuated at the Danish site (results not shown) where the delay between barley and pea emergence dates were large (see \$3.2). Moreover, sowing barley before peas significantly reduced $(\mathrm{p}<0.01)$ pea grain yield by $30 \%$ and consequently, as the intercrop's advantage over sole crops depends in our simulated conditions on pea yield elaboration (see \$3.2), it involved a reduction of $5 \%$ in the total grain yield LER averaged over all three sites (Table 5 , for additive design). However, there was no effect at the French site and only a small one in the Danish one. Although the effect was not statistically significant even at the English site, a reduction of $10 \%$ would be agronomically important. At the French site, where barley is more competitive than peas, it appeared that sowing pea before barley was preferable, while at the Danish and English sites,

simultaneous sowing was equally good (Table 5). This shows that the sowing strategy may be considered when investigating the advantage of IC over SC, and must be adapted to the location, being dependent on temperature (and thus latitude).

\section{ii) How to use basic management tools like sowing density and seed proportion of each species in the}

\section{intercrop to improve total grain yield and $\mathrm{N}$ use efficiency?}

The results showed that the total IC grain yield is influenced neither by the density nor by the respective proportions of barley and pea seeds (Table 6). However, there is a significant difference in barley grain yield between a $\mathrm{Bp}$ design (1/3pea $+2 / 3$ barley $)$ and a $\mathrm{Pb}$ design (2/3pea $+1 / 3$ barley), with $11 \%$ more barley grain in $\mathrm{Bp}$. This could be relevant when what may be wanted is a given 20 proportion of barley and pea in the total yield.

Total plant density has no significant effect on the total $\mathrm{N}$ use efficiency (NUE), calculated as the ratio of the final pea+barley crop dry matter production to the pea+barley intercrop's $\mathrm{N}$ accumulation, whereas the pea/barley partitioning is, due to the barley NUE, enhanced in the Bp design (Table 6). Though there is no significant difference between pea NUE when comparing $\mathrm{Bp}$ and $\mathrm{Pb}$; pea $\mathrm{N}_{2}$ 25 fixation as a fraction of pea total $\mathrm{N}$ increased significantly $(\mathrm{P}<0.05)$ from $\mathrm{Bp}(61.8 \%)$ to $\mathrm{Pb}(64.7 \%)$. However the fact that barley NUE is lower in the $\mathrm{Pb}$ design indicates that an increase in $\mathrm{N}_{2}$ fixation does not prevent interspecies competition for soil mineral nitrogen. 


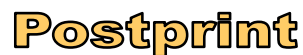

Version définitive du manuscrit publié dans / Final version of the manuscript published in : European Journal of Agronomy, 2009, vol.31, no.2, 85-98, DOI: 10.1016/j.eja.2009.04.002

These results show the small effect of density and species proportions on total grain yield. Nevertheless, they underline the interspecific offset in the use of environmental growth resources, leading to similar total grain yields whatever the pea-barley design. Finally, the pea-barley mixture, by varying the densities and proportions of the two species, seems more promising for increasing NUE than for increasing grain yield.

iii) How to optimize the use of nitrogen by choosing the most suitable preceding crop and/or soil?

As already shown in experimental conditions, the simulated results were very similar for both intercrop designs, so we just gave the figures here for the additive design (Fig. 7). Treatments "om" 10 and "oM" correspond to the lowest organic nitrogen content, and treatments "Om" and "OM" to the highest. Treatments "om" and "Om" correspond to lowest initial mineral nitrogen profile, and treatments "oM" and "OM" to the highest. Grain yield (Fig. 7a) and plant N content (Fig. 7b) significantly responded to soil initial mineral nitrogen content $(\mathrm{p}<0.01)$ whereas no significant differences resulted from organic nitrogen content treatments. Obviously for pea the soil nitrogen 15 availability had no significant influence either on grain yield and plant $\mathrm{N}$ content or on $\mathrm{N}_{2}$ fixation, whereas simulated pea grain yield was increased by $11 \%$ in Denmark and France, and $6 \%$ in England with a $12 \mathrm{~g} \mathrm{~N} \cdot \mathrm{m}^{-2}$ increase in initial mineral $\mathrm{N}$ content for a nominal soil organic $\mathrm{N}$ content. Though the model formalizations include the adverse effect of soil nitrate availability on nodule formation and nitrogenase activity, the assumed amounts of soil nitrate in these simulations may be below this

20 inhibiting threshold. As far as barley is concerned, the soil nitrogen status and in particular the initial mineral $\mathrm{N}$ content had a large and significant $(\mathrm{p}<0.01)$ influence (barley grain yield was increased by $27 \%$ in Denmark and France, and plant N content was increased by $92 \%$ in Denmark and by $67 \%$ in France with a $12 \mathrm{~g} \mathrm{~N} \cdot \mathrm{m}^{-2}$ increase in initial mineral $\mathrm{N}$ content for a nominal soil organic $\mathrm{N}$ content). Indeed, increasing nitrogen availability at the beginning of growth significantly decreased the nitrogen stress index of the barley crop (Fig. 8), which was strongly linked to barley grain yield (see §3.2) and reduced the proportion of peas in the IC yield, as already shown experimentally for a wheat-pea intercrop by Ghaley et al. (2005). The differences between locations, intended to represent soil and weather differences in terms of rainfall (for leaching) and temperature (for mineralization) applied at a 


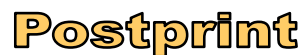

Version définitive du manuscrit publié dans / Final version of the manuscript published in : European Journal of Agronomy,

2009, vol.31, no.2, 85-98, DOI: 10.1016/j.eja.2009.04.002

certain soil fertility, were much more apparent on plant nitrogen figures (Figure $7 b$ ). Indeed, the interaction between treatment and site had a significant effect $(\mathrm{p}<0.01)$ on the nitrogen stress index during the reproductive growth of the barley crop. Maximum barley responses to organic nitrogen increase in England and France confirmed the role of temperature : colder in Denmark, they slow

5 down mineralization during winter (barley grain yield is increased by $9 \%$ in England whereas it does not increase in Denmark when organic nitrogen content was 20\% more than the nominal content of the soil). Similarly, the bigger barley response to initial mineral nitrogen content in Denmark and France confirmed that England is rainier, causing leaching (barley grain yield was increased by $27 \%$ in Denmark and France whereas it was increased by only $13 \%$ in England with a $12 \mathrm{~g} \mathrm{~N} \cdot \mathrm{m}^{-2}$ increase in 10 initial mineral $\mathrm{N}$ content). Similar trends were observed for plant nitrogen accumulation.

These results underline the importance of a long term-strategy, including mineralization management through organic residue supply and rotation management, in order to increase soil nitrogen availability, always favoring intercrop total grain yield and $\mathrm{N}$ accumulation.

\section{4. Conclusion}

The STICS intercrop model was first used as a diagnosis tool to compare pea-barley intercropping with sole cropping, in terms of total grain and nitrogen yields. The intercrop advantage on sole crops depended, in our conditions of low levels of nitrogen supply, on pea yield elaboration within the intercrop. In the intercrop, pea growth appeared to be strongly linked to soil moisture through

20 nodulation activity, and barley yield was determined by nitrogen uptake and light interception due to its height relative to pea.

Secondly the use of the model to explore options for managing these systems underlined the interspecific offset in the use of environmental growth resources. The simulation results led to similar total grain yields whatever the pea-barley design (as a combination of sowing density and seed proportion of each species) or whatever the sowing delay schedule. Nevertheless, total grain yields and plant $\mathrm{N}$ contents increased significantly with soil mineral nitrogen contents, especially in the situations where barley was less competitive. Mineralization management through organic residue supply also 


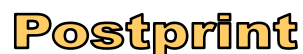

Version définitive du manuscrit publié dans / Final version of the manuscript published in : European Journal of Agronomy, 2009, vol.31, no.2, 85-98, DOI: 10.1016/j.eja.2009.04.002

contributed to barley grain yield and nitrogen content by favoring winter climate conditions (mild temperature and limited rainfall).

Long term simulations, with or without catch crops, might help to explain soil organic matter dynamics under such crops (Beaudoin et al., 2008) and thus would help us to explore options for crop 5 residue management in order to optimize intercrop production while reducing nitrate leaching (Whitmore and Shröder, 2007). Furthermore, the study of competition for light, through the relative height of the two species, and investigation of spatial heterogeneity, could be extended using functional structural models coupling architectural and functional descriptions of the system (de Reffye et al., 2008). Lastly, studying these intercropping systems in realistic organic farming 10 conditions will require disease incidence and weed competition to be introduced into the crop model involved.

Acknowledgements: We gratefully acknowledge the ESA team, Angers, France for their comprehensive work in collecting and organizing experimental data from each partner. The Intercrop 15 project was funded by the European Commission (see www.Intercrop.dk) under the 5th Framework Programme, Key Action 5 - Sustainable Agriculture.

\section{References}

Altieri, M.A. 1991. Traditional farming in Latin America. The Ecologist 2, 93-96.

Amarger, N., Mariotti, A., Mariotti, F., Dürr, J.C., Bourguignon, C., Lagacherie, B. 1979. Estimate of symbiotically fixed $\mathrm{N}$ in field grown soybeans using variations in ${ }^{15} \mathrm{~N}$ natural abundance. Plant Soil $52,269-280$ 


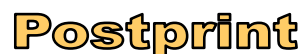

Version définitive du manuscrit publié dans / Final version of the manuscript published in : European Journal of Agronomy,

Andrews, D.J., Kassam, A.H., 1976. The importance of multiple cropping in increasing world food supplies. In: Papendick, R.I., Sanchez, A., Triplett, G.B. (Eds.), Multiple Cropping. ASA Special Publication 27, American Society of Agronomy, Madison, pp 1-10.

5 Beaudoin, N., Launay, M., Sauboua, E., Ponsardin, G., Mary, B. 2008. Evaluation of the soil-crop model STICS over 8 years against the "on farm" database of bruyères catchment. European Journal of Agronomy 29, 46-57.

Bellostas, N., Hauggaard-Nielsen, H., Andersen, M.K., Jensen, E.S. 2003. Early interference dynamics 10 in intercrops of pea, barley and oilseed rape. Biol. Agric. Hortic. 21, 337-348.

Berntsen, J., Hauggard-Nielsen, H., Olesen, J. E., Petersen, B. M., Jensen, E. S., Thomsen, A. 2004. Modelling dry matter production and resource use in intercrops of pea and barley. Field Crops Research 88, 69-83.

15

Brisson, N., Itier, B., L’Hotel, J.C., Lorendeau, J.Y. 1998. Parameterization of the ShuttleworthWallace model to estimate daily maximum transpiration for use in crop models. Ecological Modelling $107,159-169$.

20 Brisson, N., Gary, C., Justes, E., Roche, R., Mary, B., Ripoche, D., Zimmer, D., Sierra, J., Bertuzzi, P., Burger, P., Bussière, F., Cabidoche, Y.M., Cellier, P., Debaeke, P., Gaudillère, J.P, Maraux, F., Seguin, B., Sinoquet, H. 2003. An overview of the crop model STICS. European Journal of Agronomy $18,309-332$

Brisson, N., Bussière, F., Ozier-Lafontaine, H., Tournebize, R., Sinoquet, H. 2004. Adaptation of the crop model STICS to intercropping. Theoretical basis and parameterisation. Agronomie 24, 409-421. 


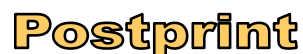

Version définitive du manuscrit publié dans / Final version of the manuscript published in : European Journal of Agronomy, 2009, vol.31, no.2, 85-98, DOI: 10.1016/j.eja.2009.04.002

Brisson, N., Launay, M., Mary, B., Beaudoin, N., 2009. Conceptual basis, formalisations and parameterization of the STICS crop model. Quae, Paris.

Caldwell, R.M., Hansen, J.W., 1993. Simulation of multiple cropping systems with CropSys. In:

5 Penning de Vries, F., Teng, P., Metselaar, K. (Eds.), Systems Aproaches for Agricultural Development. Kluwer Academic Publishers, Dordrecht, pp 397-412.

Chen, C. C., Westcott, M., Neill, K., Wichman, D., Knox, M. 2004. Row configuration and nitrogen application for barley-pea intercropping in Montana. Agronomy Journal 96, 1730-1738.

Corre-Hellou, G., 2005. Acquisition de l'azote dans des associations pois-orge (Pisum sativum L. Hordeum vulgare L.) en relation avec le fonctionnement du peuplement. PhD. thesis, ESA, Angers.

Corre-Hellou, G., Crozat, Y., 2004. Interspecific competition for soil $\mathrm{N}$ in pea-barley mixtures during the vegetative phase and consequences of $\mathrm{N}_{2}$ fixation. In: AEP (Ed.), Proceedings of the $5^{\text {th }}$ European Conference on Grain Legumes, Dijon, pp 65-66.

Corre-Hellou, G, Fustec, J, Crozat, Y. 2006. Interspecific competition for soil $\mathrm{N}$ and its interaction with N-2 fixation, leaf expansion and crop growth in pea-barley intercrops. Plant and Soil 282, 195208.

Corre-Hellou, G., Brisson, N., Launay, M., Fustec, J., Crozat, Y. 2007. Effect of root depth penetration on soil nitrogen competitive interactions and dry matter production in pea-barley intercrops given different soil nitrogen supplies. Field Crops Research 103, 76-85. 


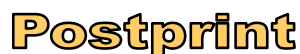

Version définitive du manuscrit publié dans / Final version of the manuscript published in : European Journal of Agronomy, 2009, vol.31, no.2, 85-98, DOI: 10.1016/j.eja.2009.04.002

De Reffye, P., Heuvelink, E., Barthélémy, D., Cournède, P.H., 2008. Plant growth models. In: Jorgensen, S.E., Fath, B.D. (Eds.), Ecological Models, Vol. [4] of Encyclopedia of Ecology. Elsevier, Oxford, pp 2824-2837.

5 De Wit, C.T., Van den Bergh, J.P. 1965. Competition between herbage plants. Neth. J. Agric. Sci. 13, 212-221.

Dumas, J.B., 1981. Sur les procédés de l'analyse organique. Annal. de Chimie. XLVII, 195-213.

10 Ghaley, B.B., Hauggaard Nielsen, H., Hogh-Jensen, H., Jensen, E.S. 2005. Intercropping of wheat and pea as influenced by nitrogen fertilization. Nutrient cycling in agroecosystems 73, 201-212.

Hauggaard-Nielsen, H., Ambus, P., Jensen, E.S. 2001a. Interspecific competition $\mathrm{N}$ use and interference with weeds in pea-barley intercropping. Field Crops Research 70, 101-109.

Hauggaard-Nielsen, H., Ambus, P., Jensen, E.S. 2001b. Temporal and spatial distribution of roots and competition for nitrogen in pea-barley intercrops-a field study employing P-32 technique. Plant Soil $236,63-74$.

20 Hauggaard-Nielsen, H., Andersen, M.K., Jørnsgaard, B., Jensen, E.S., 2006. Density and relative frequency effects on competitive interactions and resource use in pea-barley intercrops. Field Crops Research 95, 256-267.

Huth, N. I., Carberry, P. S., Poulton, P. L., Brennan, L. E., Keating, B. A., 2003. A framework for 


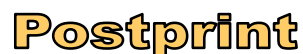

Version définitive du manuscrit publié dans / Final version of the manuscript published in : European Journal of Agronomy,

Science B.V. (Ed.), Proceeding of the 2nd International Symposium on Modelling Cropping Systems, Florence, pp 171-185.

Jensen, E.S. 1996. Grain yield, symbiotic $\mathrm{N}_{2}$ fixation and inter-specific competition for inorganic $\mathrm{N}$ in pea-barley intercrops. Plant Soil 182, 25-38.

Karray, J. A., Lhomme, J. P., Masmoudi, M. M., Mechlia, N. B. 2008. Water balance of the olive treeannual crop association: a modeling approach. Agricultural Water Management 95, 575-586.

10 Kiniry, J. R., Blanchet, R., Gassman, P. W., Debaeke P. 1992. A general process-oriented model for two competing plant species. Trans. ASAE 35, 801-810.

Knott, C.M. 1987. A key for stages of development of the pea (Pisum sativum). Annals of applied Biology 111, 233-245.

Kwabiah, A. B. 2004. Biological efficiency and economic benefits of pea-barley and pea-oat intercrops. Journal of Sustainable Agriculture 25, 117-128.

Lamanda, N., Dauzat, J., Jourdan, C., Martin, P., Malézieux, E. 2008. Using 3D architectural models to assess light availability and root bulkiness in coconut agroforestry systems. Agroforestry systems $72,63-74$

Mariotti, A., Mariotti, F., Amarger, N. 1980. Fractionnements isotopiques de l'azote lors des processus d'absorption des nitrates et de fixation de l'azote atmosphérique par les plantes. Physiol. Veg. 18, 163 181. 
Ofori, F., Stern, W.R. 1987. Cereal-legume intercropping systems. Adv. Agron. 41, 41-90.

Pridham, J. C., Entz, M. H. 2008. Intercropping spring wheat with cereal grains, legumes, and oilseeds 5 fails to improve productivity under organic management. Agronomy Journal 100, 1436-1442.

S-PLUS, 2001. S-PLUS 6 for Windows, Guide to Statistics, Volume 1, Insightful Corporation, Seattle, Washington, USA.

10 Shuttleworth, W.J., Wallace, J.S. 1985. Evaporation from sparse canopy, an energy combination theory, Q.J. Roy. Meteor. Soc. 111, 839-855.

Snaydon, R.W., Satorre, E.H. 1989. Bivariate diagrams for plant competition data: modifications and interpretation. J. Appl. Ecol. 26, 1043-1057.

15

Sonohat, G., Sinoquet, H., Varlet-Grancher, C., Rakocevic, M., Jacquet, A., Simon, J.C., Adam, B. 2002. Leaf dispersion and light partitioning in three-dimensionally digitized tall fescue-white clover mixtures. Plant, Cell and Environment 25, 529-538.

20 Szumigalski, A. R., Van Acker, R.C. 2006. Nitrogen yield and land use efficiency in annual sole crops and intercrops. Agronomy Journal 4, 1030-1040.

Szumigalski, A. R., Van Acker, R. C. 2008. Land equivalent ratios, light interception, and water use in annual intercrops in the presence or absence of in-crop herbicides. Agronomy Journal 100, 1145-1154. 
Tottman, D.R. 1987. The decimal code for the growth stages of cereals, with illustrations. Ann. Appl. Biol. 110, 441-5454.

5 Tsubo, M., Walker, S.R., Ogindo, H.O. 2005. A simulation model of cereal-legume intercropping systems for semi-arid regions I. Model development. Field Crops Research 93, 10-22.

Vandermeer, J., 1989. The Ecology of Intercropping. In: Cambridge University Press (Ed.), Cambridge.

10

Wallace, J.S., 1995. Towards a coupled light partitioning and transpiration model for use in intercrops and agroforestry. In: Sinoquet, H., Cryz, P. (Eds), Ecophysiology of tropical intercropping, INRA Editions, Versailles, pp 153-162.

15 Whitmore, A. P., Schroder, J. J. 2007. Intercropping reduces nitrate leaching from under field crops without loss of yield: a modelling study. European Journal of Agronomy 27, 81-88.

Willey, R.W. 1979. Intercropping - its importance and research needs. Part 1. Competition and yield advantages. Field Crop Abstr. 32, 2-10.

Wu, L., Baddeley, J. A., Watson, C. A. 2005. Designer root systems - the value of modelling to determine optimum root systems for different end uses. In: Association of Applied Biologists (Eds.), Roots and the Soil Environment II, Sutton Bonington, pp 11-16. 


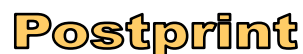

Version définitive du manuscrit publié dans / Final version of the manuscript published in : European Journal of Agronomy, 2009, vol.31, no.2, 85-98, DOI: 10.1016/j.eja.2009.04.002

Zhang, F., Shen, J., Li, L., Liu, X. 2004. An overview of rhizosphere processes related with plant nutrition in major cropping systems in China. Plant and Soil 260, 89-99.

Zhang, L., Spiertz, J. H. J., Zhang, S., Li, B., van der Werf, W. 2008. Nitrogen economy in relay 5 intercropping systems of wheat and cotton. Plant and soil 303, 55-68. 
Version définitive du manuscrit publié dans / Final version of the manuscript published in : European Journal of Agronomy, 2009, vol.31, no.2, 85-98, DOI: 10.1016/j.eja.2009.04.002

\section{Tables}

Table 1: Soil characteristics for all field trials.

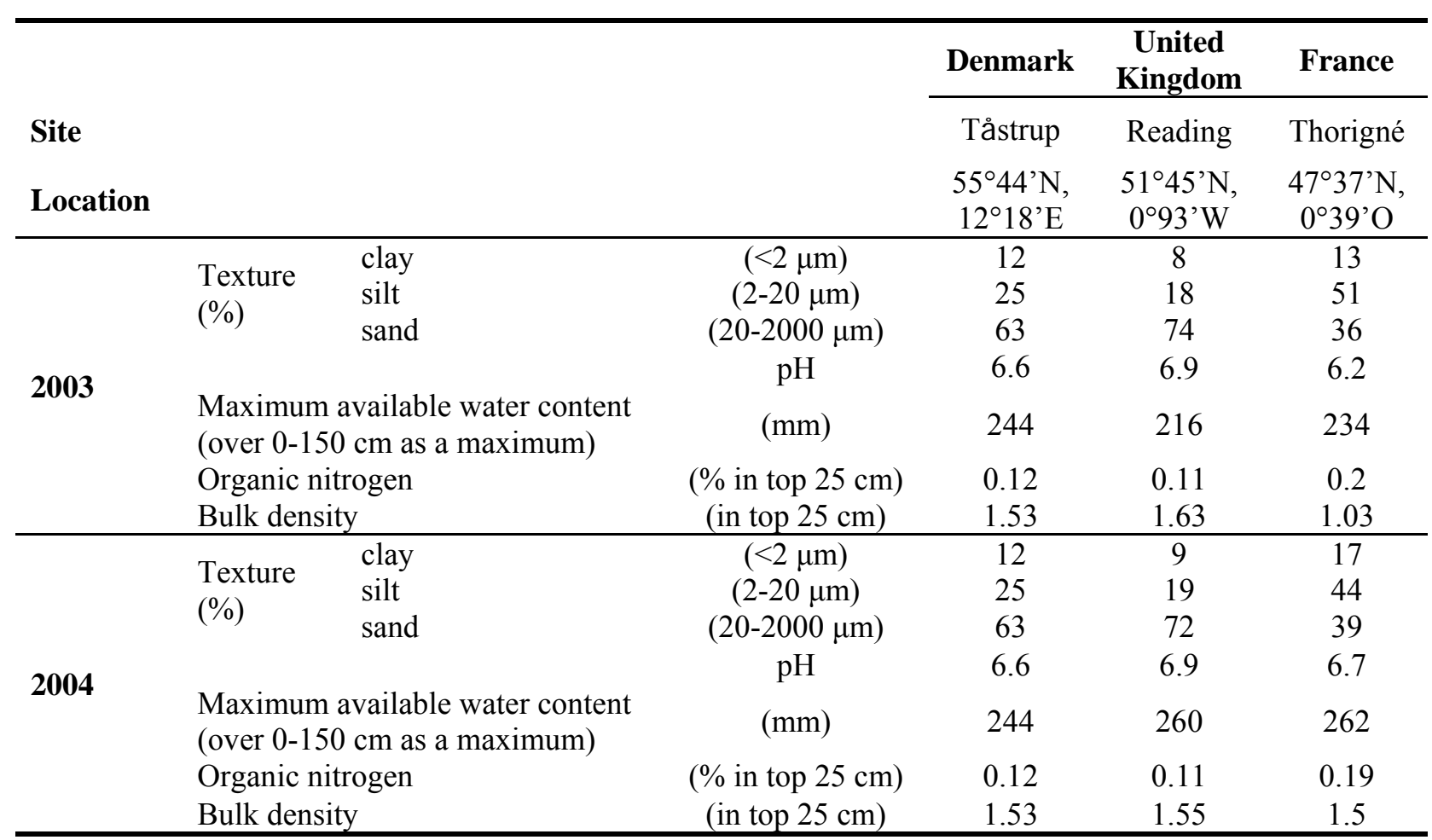


Version définitive du manuscrit publié dans / Final version of the manuscript published in : European Journal of Agronomy, 2009, vol.31, no.2, 85-98, DOI: 10.1016/j.eja.2009.04.002

Table 2: Sowing and growth cycle characteristics for all field trials.

\begin{tabular}{|c|c|c|c|c|}
\hline Year & $\begin{array}{l}\text { Sowing and growth cycle } \\
\text { characteristics }\end{array}$ & Denmark & $\begin{array}{c}\text { United } \\
\text { Kingdom }\end{array}$ & France \\
\hline \multirow{7}{*}{2003} & Sowing date & 3 April & 16 March & 11 March \\
\hline & $\begin{array}{l}\text { Cycle duration from } \\
\text { pea-barley sowing to } \\
\text { pea-barley harvest }\end{array}$ & $\begin{array}{l}113 \text { days } \\
\left(1555^{\circ} \mathrm{C} \cdot \mathrm{d}\right)\end{array}$ & $\begin{array}{l}134 \text { days } \\
\left(1843^{\circ} \mathrm{C} \cdot \mathrm{d}\right)\end{array}$ & $\begin{array}{l}120 \text { days } \\
\left(1877^{\circ} \mathrm{C} \cdot \mathrm{d}\right)\end{array}$ \\
\hline & $\begin{array}{l}\text { Sowing density for sole } \\
\text { crops and additive design }\end{array}$ & & & \\
\hline & pea & 90 & 110 & 113 \\
\hline & barley & 150 & 200 & 184 \\
\hline & $\begin{array}{l}\text { Sowing density for } \\
\text { replacement design } \\
\text { (pea/barley) }\end{array}$ & $45 / 150$ & $55 / 200$ & $57 / 184$ \\
\hline & Sowing date & 16 April & 17 March & 10 March \\
\hline \multirow{5}{*}{2004} & $\begin{array}{l}\text { Cycle duration from } \\
\text { pea-barley sowing to } \\
\text { pea-barley harvest }\end{array}$ & $\begin{array}{c}112 \text { days } \\
\left(1616^{\circ} \mathrm{C} \cdot \mathrm{d}\right)\end{array}$ & $\begin{array}{l}131 \text { days } \\
\left(1726^{\circ} \mathrm{C} \cdot \mathrm{d}\right)\end{array}$ & $\begin{array}{c}123 \text { days } \\
\left(1696^{\circ} \mathrm{C} \cdot \mathrm{d}\right)\end{array}$ \\
\hline & $\begin{array}{l}\text { Sowing density for sole } \\
\text { crops and additive design }\end{array}$ & & & \\
\hline & pea & 90 & 110 & 112 \\
\hline & barley & 150 & 200 & 220 \\
\hline & $\begin{array}{l}\text { Sowing density for } \\
\text { replacement design } \\
\text { (pea/barley) }\end{array}$ & $45 / 150$ & $55 / 200$ & $55 / 220$ \\
\hline
\end{tabular}


Version définitive du manuscrit publié dans / Final version of the manuscript published in : European Journal of Agronomy, 2009, vol.31, no.2, 85-98, DOI: 10.1016/j.eja.2009.04.002

Table 3: Simulated Grain yield LER and Plant Nitrogen LER for the different cropping systems, at English, Danish and French locations.

\begin{tabular}{|c|c|c|c|c|c|}
\hline \multirow{2}{*}{\multicolumn{2}{|c|}{ LER }} & \multicolumn{2}{|c|}{ Grain yield } & \multicolumn{2}{|c|}{ Plant $N$ content } \\
\hline & & Additive & Replacement & Additive & Replacement \\
\hline \multirow{5}{*}{ location } & England & 1.24 & 1.25 & 1.29 & 1.31 \\
\hline & \multirow{2}{*}{ Denmark } & $\begin{array}{c}(0.46) \\
1.21\end{array}$ & $\begin{array}{c}(0.42) \\
1.08\end{array}$ & $\begin{array}{c}(0.52) \\
1.35\end{array}$ & $\begin{array}{c}(0.55) \\
1.15\end{array}$ \\
\hline & & $(0.24)$ & $(0.13)$ & $(0.38)$ & $(0.27)$ \\
\hline & \multirow{2}{*}{ France } & 1.11 & 1.12 & 1.07 & 1.07 \\
\hline & & (0.09) & $(0.08)$ & $(0.09)$ & $(0.09)$ \\
\hline
\end{tabular}

Standard deviations are shown in parentheses below the mean LER values 
Version définitive du manuscrit publié dans / Final version of the manuscript published in : European Journal of Agronomy, 2009, vol.31, no.2, 85-98, DOI: 10.1016/j.eja.2009.04.002

Table 4: Coefficient of variation of the simulated grain yield over years, for the different cropping systems, at English, Danish and French locations.

\begin{tabular}{|r|r|}
\hline & Crop grain yield \\
\hline
\end{tabular}

\begin{tabular}{l|ccc|ccc|cc} 
& \multicolumn{4}{|c|}{ Pea } & \multicolumn{3}{c|}{ Barley } & \multicolumn{3}{c}{ Total grain yield } \\
\hline $\begin{array}{l}\text { Coefficient of } \\
\text { variation }\end{array}$ & SC & Additive & Replacement & SC & Additive & Replacement & Additive & Replacement \\
\hline England & 0.25 & 0.28 & 0.29 & 0.32 & 0.21 & 0.23 & 0.21 & 0.22 \\
Denmark & 0.21 & 0.31 & 0.32 & 0.30 & 0.43 & 0.46 & 0.23 & 0.24 \\
France & 0.29 & 0.48 & 0.49 & 0.24 & 0.19 & 0.20 & 0.29 & 0.29 \\
\hline
\end{tabular}


Version définitive du manuscrit publié dans / Final version of the manuscript published in : European Journal of Agronomy, 2009, vol.31, no.2, 85-98, DOI: 10.1016/j.eja.2009.04.002

Table 5: Simulated Grain yield LER for additive design, when sowing barley before pea, barley and pea at the same date, and pea before barley, at Danish, English, and French locations.

\begin{tabular}{llccc}
\hline Grain Yield LER & \multicolumn{3}{c}{ Additive design } \\
& & $\begin{array}{c}\text { Barley } \\
\text { before pea }\end{array}$ & $\begin{array}{c}\text { Same } \\
\text { sowing date }\end{array}$ & $\begin{array}{c}\text { Pea before } \\
\text { barley }\end{array}$ \\
\hline location & Denmark & $1.17 \mathrm{a}$ & $1.21 \mathrm{a}$ & $1.20 \mathrm{a}$ \\
& England & $1.12 \mathrm{a}$ & $1.24 \mathrm{a}$ & $1.22 \mathrm{a}$ \\
& France & $\mathbf{1 . 1 1} \mathbf{a}$ & $\mathbf{1 . 1 1} \mathbf{a}$ & $\mathbf{1 . 2 8} \mathbf{b}$ \\
\hline All sites & & $1.13 \mathrm{a}$ & $1.19 \mathrm{a}$ & $1.24 \mathrm{a}$ \\
\hline
\end{tabular}

Values are the mean over years.

In each row, grain yield LER values followed by the same letter are not significantly different at $p<0.01$. 
Version définitive du manuscrit publié dans / Final version of the manuscript published in : European Journal of Agronomy, 2009, vol.31, no.2, 85-98, DOI: 10.1016/j.eja.2009.04.002

Table 6: Mean of simulated grain yields and NUE (crop above-ground dry matter/crop N accumulation ratio) over sites and years, for combinations $\mathrm{Bp}((1 / 3)$ pea $+(2 / 3)$ barley) and $\mathrm{Pb}$ $((2 / 3)$ pea $+(1 / 3)$ barley $)$, and for low, recommended and high densities.

\begin{tabular}{|c|c|c|c|c|c|c|c|c|c|c|}
\hline \multirow[t]{3}{*}{ Crop } & \multicolumn{4}{|c|}{$\begin{array}{c}\text { Combination } \\
\end{array}$} & \multicolumn{6}{|c|}{ Density } \\
\hline & \multicolumn{2}{|c|}{ Grain Yield $\left(\mathrm{g} \cdot \mathrm{m}^{-2}\right)$} & \multicolumn{2}{|c|}{$\begin{array}{c}\text { Crop above-ground } \\
\text { DM (\%)/ } \\
\text { Crop N accumulation }\end{array}$} & \multicolumn{3}{|c|}{ Grain Yield $\left(\mathrm{g} \cdot \mathrm{m}^{-2}\right)$} & \multicolumn{3}{|c|}{$\begin{array}{c}\text { Crop above-ground } \\
\text { DM }(\%) / \\
\text { Crop N accumulation }\end{array}$} \\
\hline & $\mathrm{Bp}$ & $\mathrm{Pb}$ & Bp & $\mathrm{Pb}$ & low & recom & high & low & recom & high \\
\hline Pea & $137 \mathrm{a}$ & $151 \mathrm{a}$ & $3.9 \mathrm{c}$ & $3.9 \mathrm{c}$ & $187 \mathrm{a}$ & $189 \mathrm{a}$ & $190 \mathrm{a}$ & $0.38 \mathrm{c}$ & $0.39 \mathrm{c}$ & $0.39 \mathrm{c}$ \\
\hline Barley & $185 \mathrm{a}$ & $166 \mathrm{~b}$ & $8.7 \mathrm{c}$ & $8.2 \mathrm{~d}$ & $199 \mathrm{a}$ & $210 \mathrm{a}$ & $221 \mathrm{a}$ & $0.82 \mathrm{c}$ & $0.86 \mathrm{c}$ & $0.89 \mathrm{c}$ \\
\hline Total & $322 \mathrm{a}$ & $316 \mathrm{a}$ & $6.0 \mathrm{c}$ & $5.6 \mathrm{~d}$ & $307 \mathrm{a}$ & $318 \mathrm{a}$ & $332 \mathrm{a}$ & $0.56 \mathrm{c}$ & $0.58 \mathrm{c}$ & $0.61 \mathrm{c}$ \\
\hline
\end{tabular}

Values are the mean $(n=522)$

In each row, grain yield or NUE mean values followed by the same letter are not significantly different at $p<0.01$. 


\section{Figure captions}

Figure 1. Average daily air temperature $\left({ }^{\circ} \mathrm{C}\right)$, cumulative rainfall and Potential EvapoTranspiration (PET) $(\mathrm{mm})$ per decade at the Danish, English and French sites during the growth seasons 2003 and 2004. The thick grey line contains the crop cycle period.

Figure 2. 11 year (for English and French sites) and 9 year (for Danish site) average of cumulative solar radiation $\left(\mathrm{J} \cdot \mathrm{cm}^{-2}\right)$, daily air temperature $\left({ }^{\circ} \mathrm{C}\right)$ and monthly rainfall $(\mathrm{mm})$ at the Danish, English and French sites.

Figure 3. Evaluation of the model for sole crops ( $\square$ sole pea, $\Delta$ sole barley) and intercrops replacement pea, $\boldsymbol{\Delta}$ replacement barley, $\boxplus$ additive pea, $\Delta$ additive barley) by comparing observed and simulated (a) crop height (m), (b) plant nitrogen content $\left(\mathrm{g} \mathrm{N} \cdot \mathrm{m}^{-2}\right)$, (c) total aboveground dry matter $\left(\mathrm{g} \cdot \mathrm{m}^{-2}\right),(\mathrm{d})$ grain yield $\left(\mathrm{g} \cdot \mathrm{m}^{-2}\right)$ and $(\mathrm{e})$ soil mineral nitrogen content $\left(\mathrm{g} \mathrm{N} \cdot \mathrm{m}^{-2}\right)$. Values are means \pm S.E ( - line 1:1).

Figure 4. Comparison of measured (meas.) and simulated (simul.) (a) grain yields $\left(\mathrm{g} \cdot \mathrm{m}^{-2}\right)$ for pea and barley sole crops (SC) and pea and barley intercrops (IC), and (b) LER for total aboveground dry matter production, total grain yield LER and total plant nitrogen content LER over years and locations. Values are means \pm S.E ( $-\mathrm{LER}=1)$.

Figure 5. Simulated grain yields $\left(\mathrm{g} \cdot \mathrm{m}^{-2}\right)$ of pea and barley in sole cropping ("sole") and intercropping ("add" for additive design and "rep" for replacement design) in English, Danish and French locations over the $n$ years' weather records ( $n=11$ for English and French sites, and $n=9$ for Danish site). Values are means \pm S.E. 
Version définitive du manuscrit publié dans / Final version of the manuscript published in : European Journal of Agronomy, 2009, vol.31, no.2, 85-98, DOI: 10.1016/j.eja.2009.04.002

Figure 6. (a) Simulated pea grain yield $\left(\mathrm{g} \cdot \mathrm{m}^{-2}\right)$ versus simulated fixed $\mathrm{N}_{2}$ amount $\left(\mathrm{g} \mathrm{N} \cdot \mathrm{m}^{-2}\right)$, (b) simulated pea fixed $\mathrm{N}_{2}$ amount $\left(\mathrm{g} \mathrm{N} \cdot \mathrm{m}^{-2}\right)$ versus simulated water stress index, (c) simulated barley grain yield $\left(\mathrm{g} \cdot \mathrm{m}^{-2}\right)$ versus simulated nitrogen stress index, (d) simulated nitrogen stress index versus simulated barley total efficient root length $\left(\mathrm{cm}\right.$ root $\cdot \mathrm{cm}^{-2}$ soil) over years and locations for additive $(\diamond)$ and replacement $(+)$ designs; daily pea $(-)$ and barley $(-\cdot-)$ crop heights for the simulations of additive design in (e) France and (f) Denmark in 2004; (g) simulated barley grain yield versus simulated barley crop height over years in $(\Delta)$ Danish, $(+)$ English and $(\bullet)$ French locations.

Figure 7. Simulated (a) grain yields $\left(\mathrm{g} \cdot \mathrm{m}^{-2}\right)$ and (b) plant nitrogen content $\left(\mathrm{g} \mathrm{N} \cdot \mathrm{m}^{-2}\right)$ of pea and barley in additive intercropping design ("om" for nominal organic nitrogen content and a $3 \mathrm{~g}$ $\mathrm{N} \cdot \mathrm{m}^{-2}$ total mineral nitrogen profile at sowing, "oM" for nominal organic nitrogen content and a $15 \mathrm{~g} \mathrm{~N} \cdot \mathrm{m}^{-2}$ total mineral nitrogen profile at sowing, "Om" for $20 \%$ increase in the soil nitrogen organic content and a $3 \mathrm{~g} \mathrm{~N} \cdot \mathrm{m}^{-2}$ total mineral nitrogen profile at sowing, "OM" for $20 \%$ increase in the soil nitrogen organic content and a $15 \mathrm{~g} \mathrm{~N} \cdot \mathrm{m}^{-2}$ total mineral nitrogen profile at sowing in English, Danish and French locations over the $\mathrm{n}$ years' weather records ( $\mathrm{n}=11$ for English and French sites, and $\mathrm{n}=9$ for Danish site). Values are means \pm S.E.

Figure 8. Box plots of average nitrogen stress index simulated for barley in additive intercropping design ("om" for nominal organic nitrogen content and a $3 \mathrm{~g} \mathrm{~N} \cdot \mathrm{m}-2$ total mineral nitrogen profile at sowing, "oM" for nominal organic nitrogen content and a $15 \mathrm{~g} \mathrm{~N} \cdot \mathrm{m}-2$ total mineral nitrogen profile at sowing, "Om" for $20 \%$ increase in the soil nitrogen organic content and a $3 \mathrm{~g} \mathrm{~N} \cdot \mathrm{m}-2$ total mineral nitrogen profile at sowing," "OM" for $20 \%$ increase in the soil nitrogen organic content and a $15 \mathrm{~g} \mathrm{~N} \cdot \mathrm{m}-2$ total mineral nitrogen profile). The lower and upper values of the boxes 


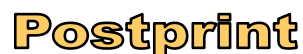

Version définitive du manuscrit publié dans / Final version of the manuscript published in : European Journal of Agronomy, 2009, vol.31, no.2, 85-98, DOI: 10.1016/j.eja.2009.04.002

correspond to the first and third quartile, while the white bold bar represents the median. Minimum and maximum values are also reported (dotted lines). 31 values are reported in each boxplot. 
Version définitive du manuscrit publié dans / Final version of the manuscript published in : European Journal of Agronomy, 2009, vol.31, no.2, 85-98, DOI: 10.1016/j.eja.2009.04.002
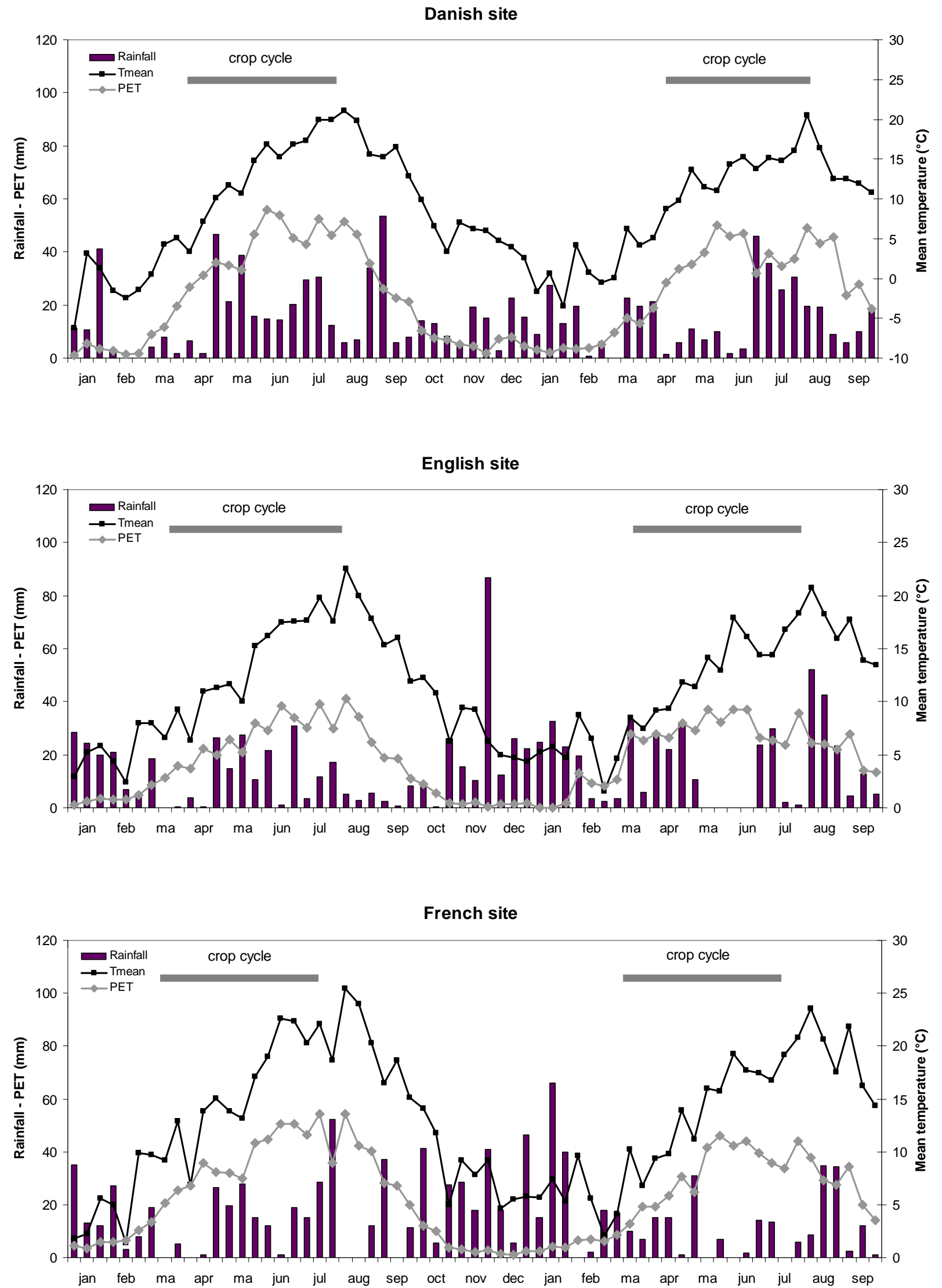

Figure 1 


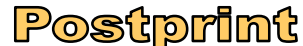

Version définitive du manuscrit publié dans / Final version of the manuscript published in : European Journal of Agronomy, 2009, vol.31, no.2, 85-98, DOI: 10.1016/j.eja.2009.04.002
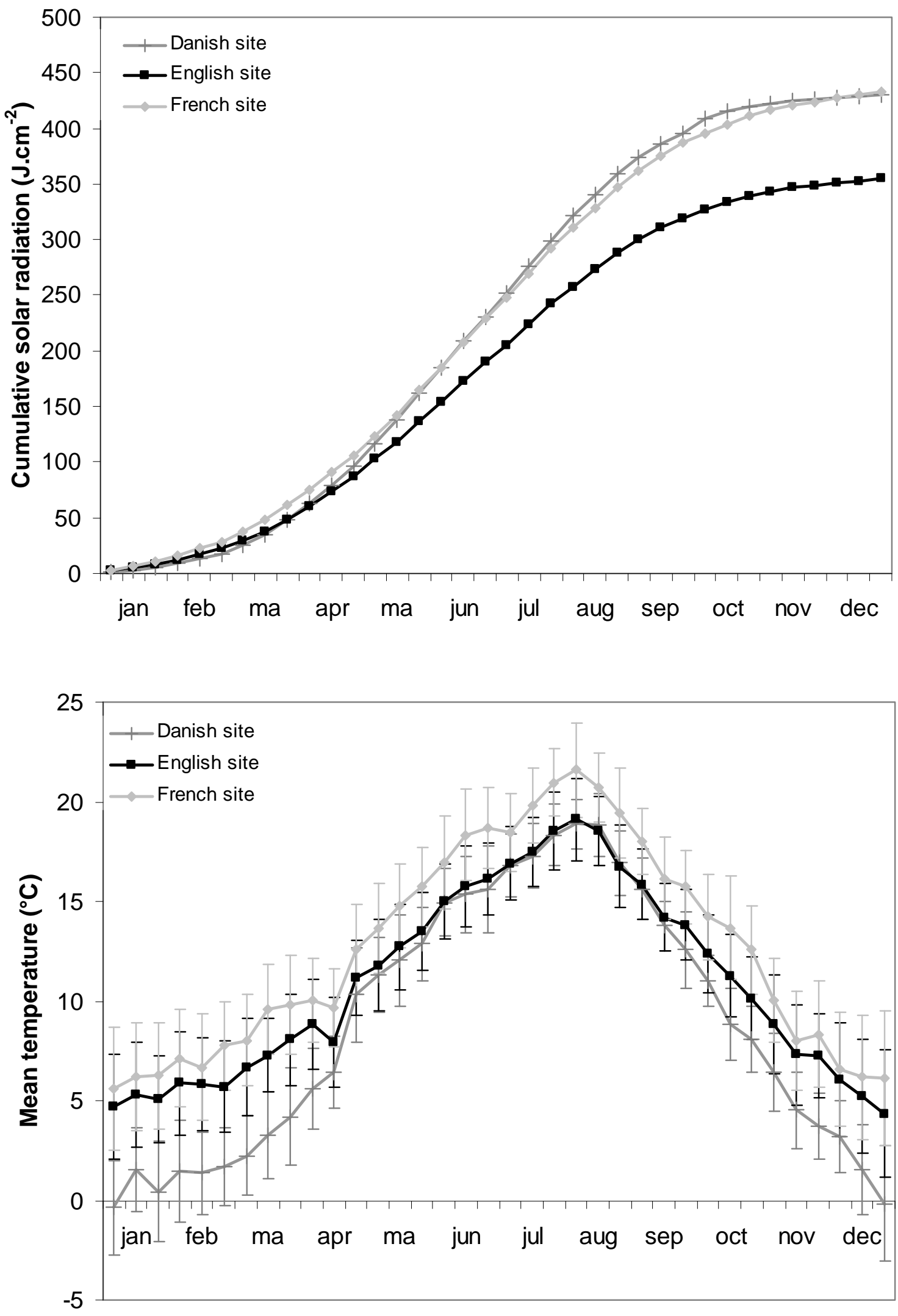

Comment citer ce document 


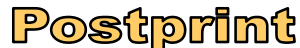

Version définitive du manuscrit publié dans / Final version of the manuscript published in : European Journal of Agronomy, 2009, vol.31, no.2, 85-98, DOI: 10.1016/j.eja.2009.04.002

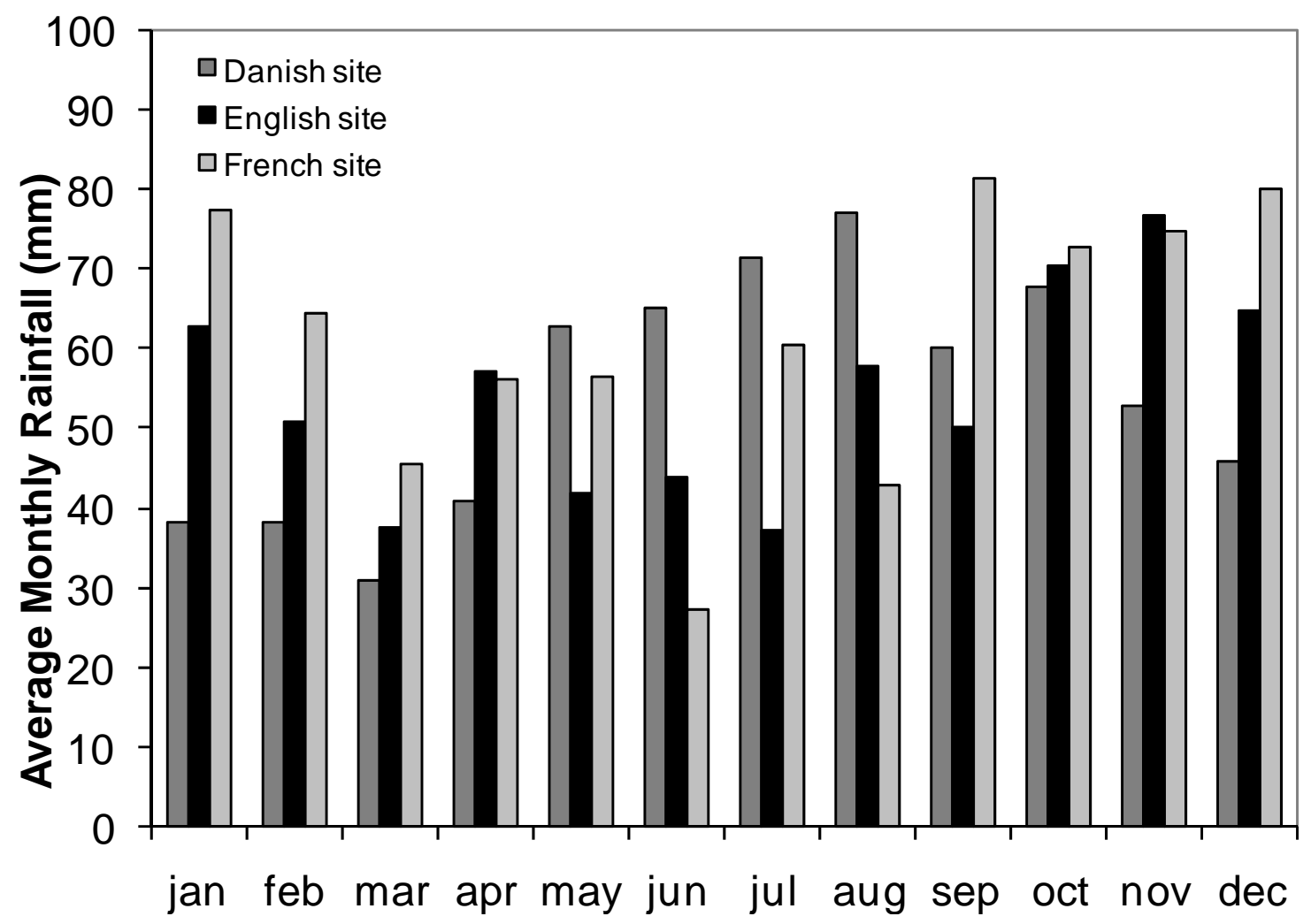

Figure 2 
Version définitive du manuscrit publié dans / Final version of the manuscript published in : European Journal of Agronomy,
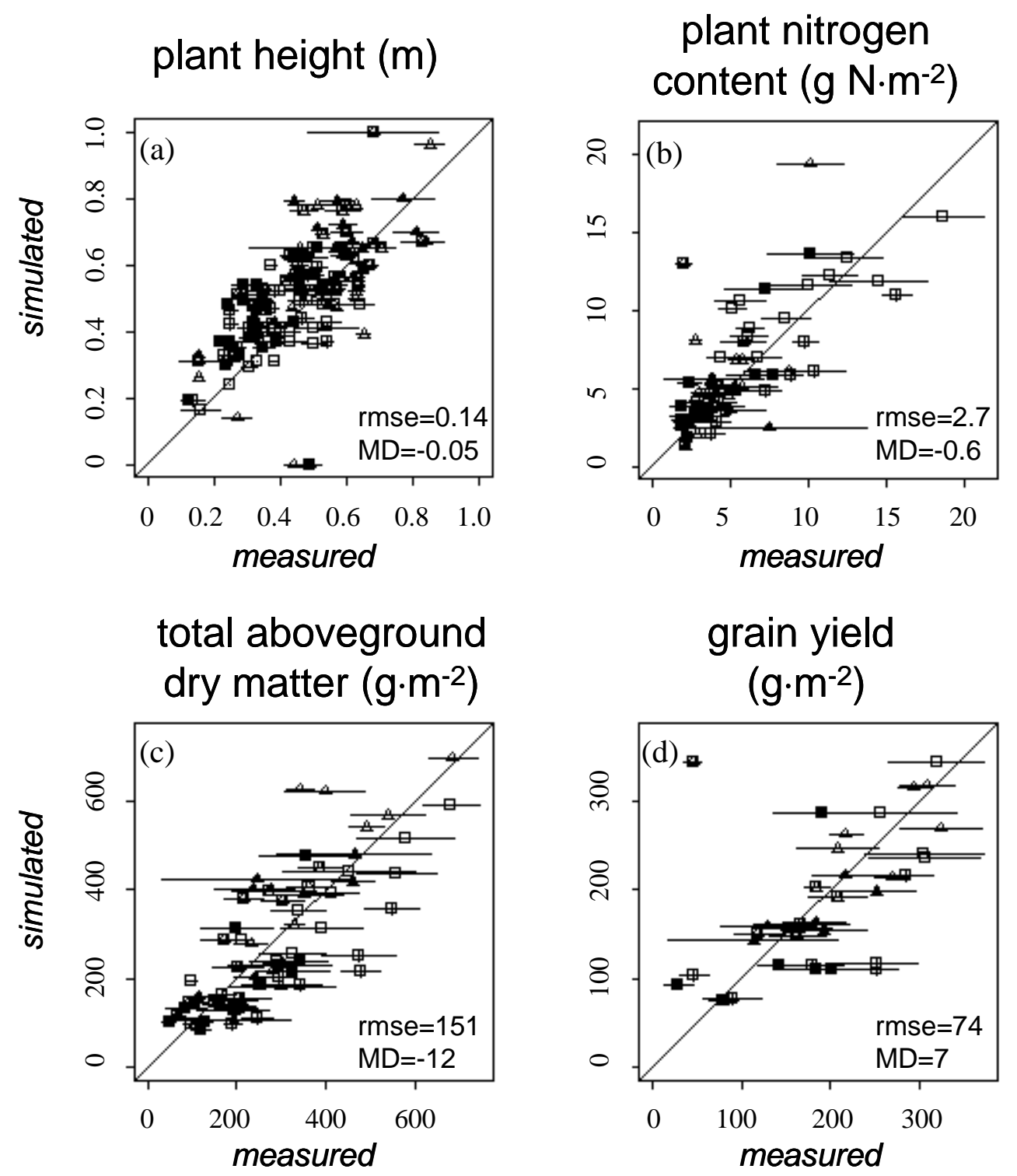

soil mineral nitrogen content (g N.m-2)

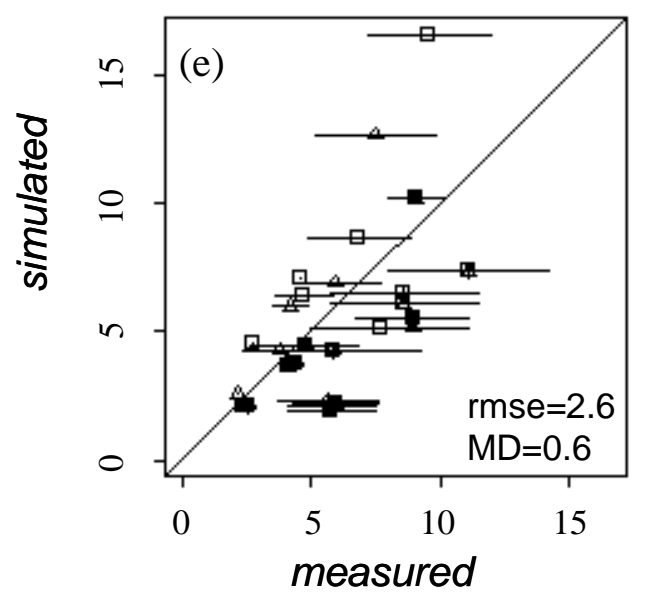

Figure 3 
Version définitive du manuscrit publié dans / Final version of the manuscript published in : European Journal of Agronomy, 2009, vol.31, no.2, 85-98, DOI: 10.1016/j.eja.2009.04.002
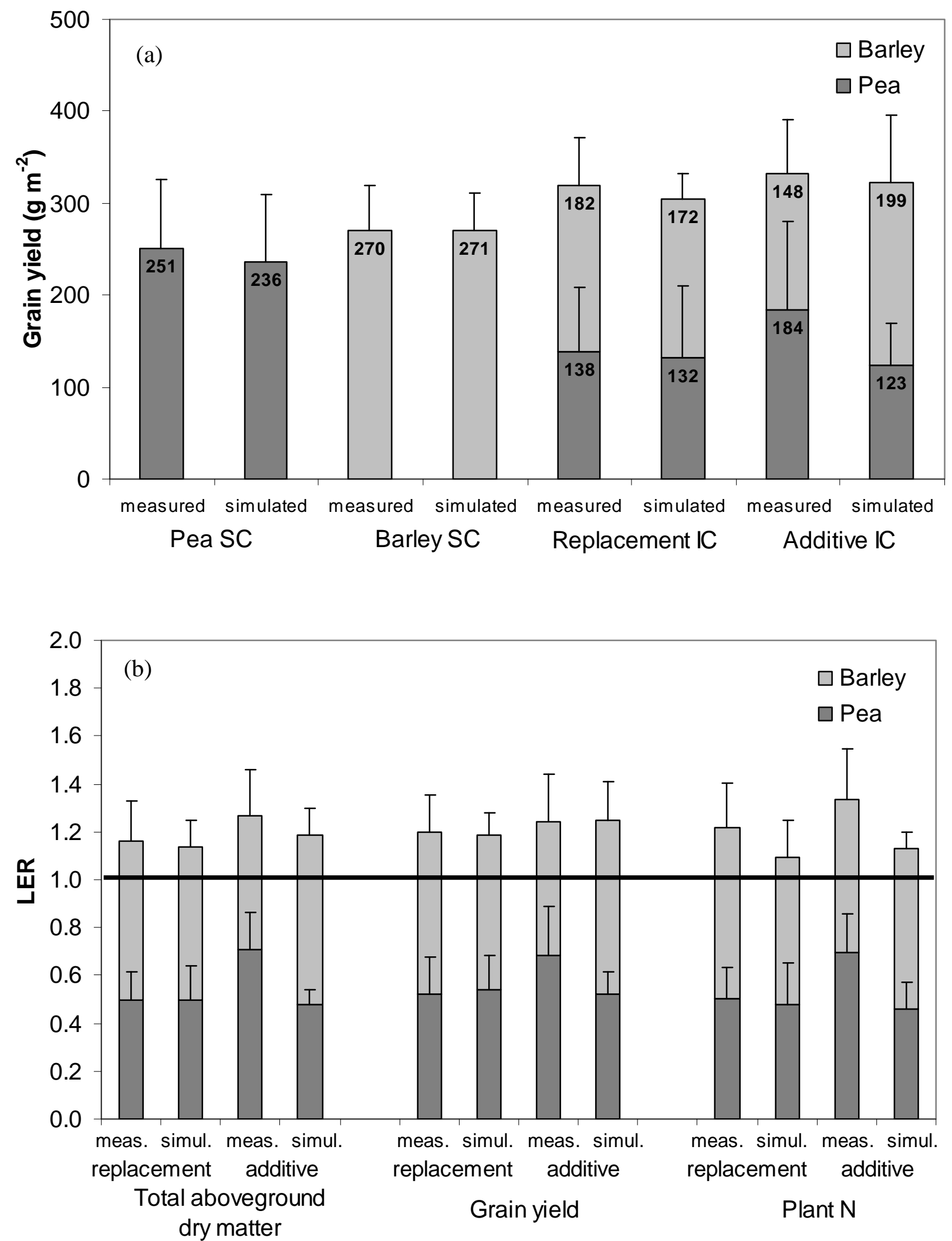

Figure 4 


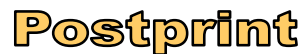

Version définitive du manuscrit publié dans / Final version of the manuscript published in : European Journal of Agronomy, 2009, vol.31, no.2, 85-98, DOI: 10.1016/j.eja.2009.04.002

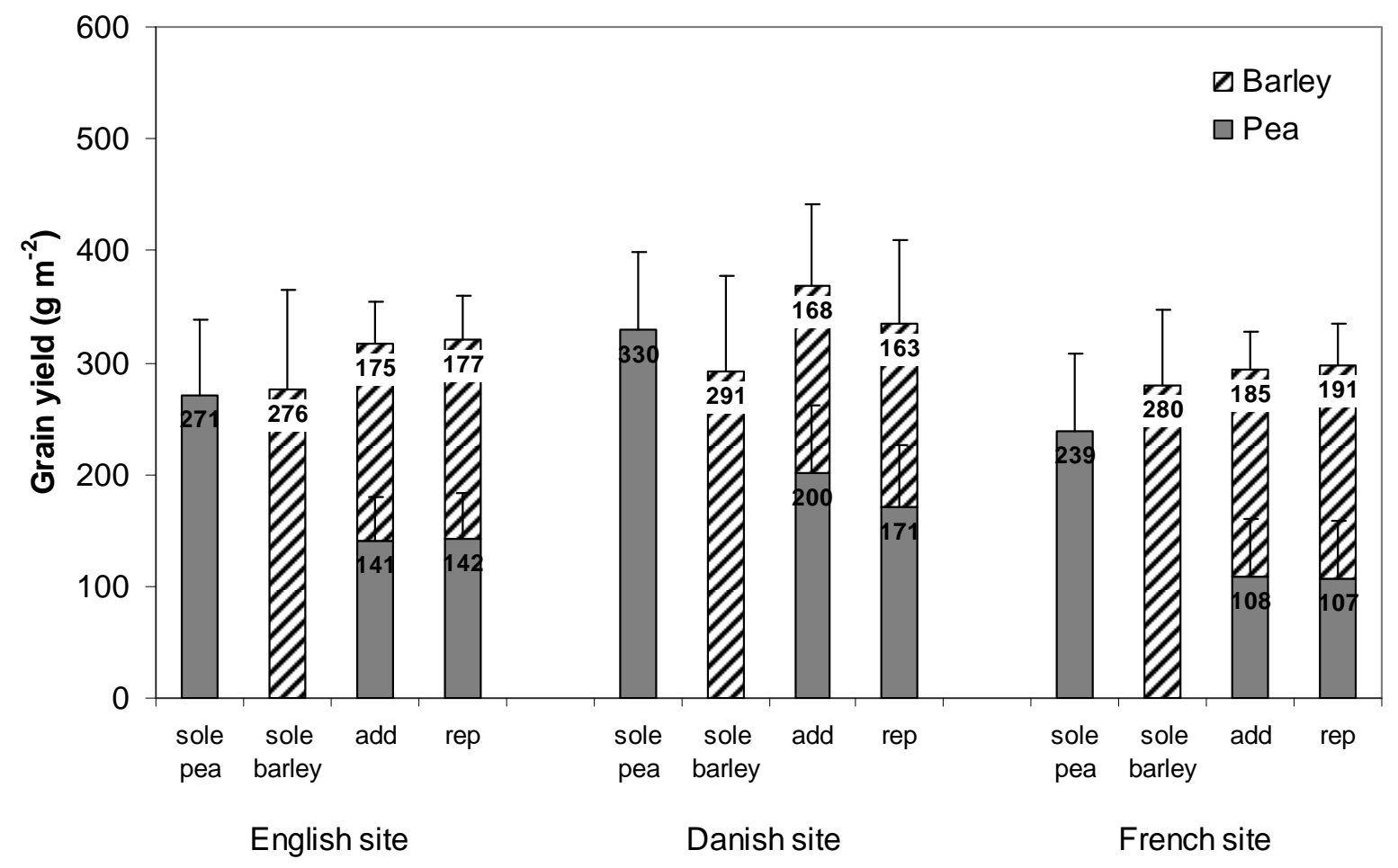

Figure 5 
Version définitive du manuscrit publié dans / Final version of the manuscript published in : European Journal of Agronomy,

(a)

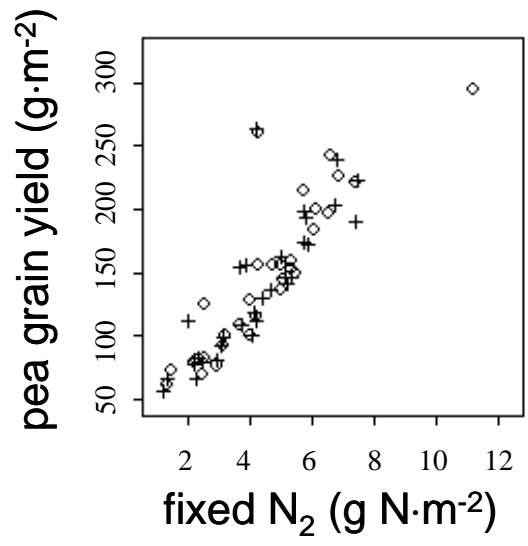

(c)

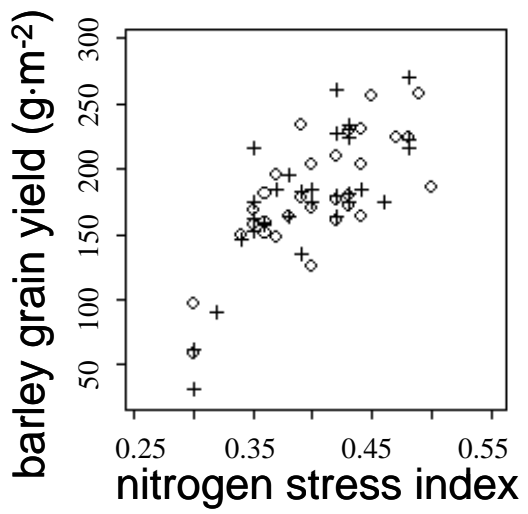

(e)

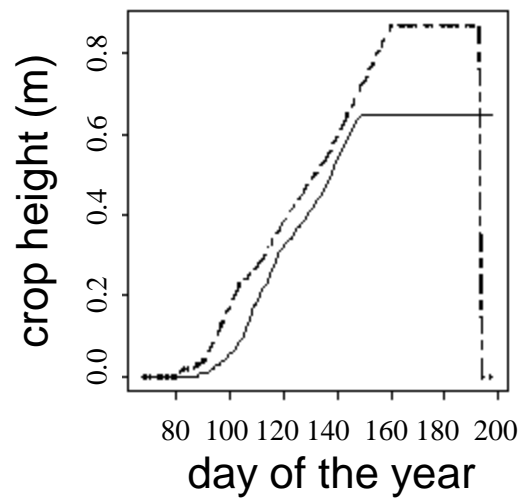

(b)

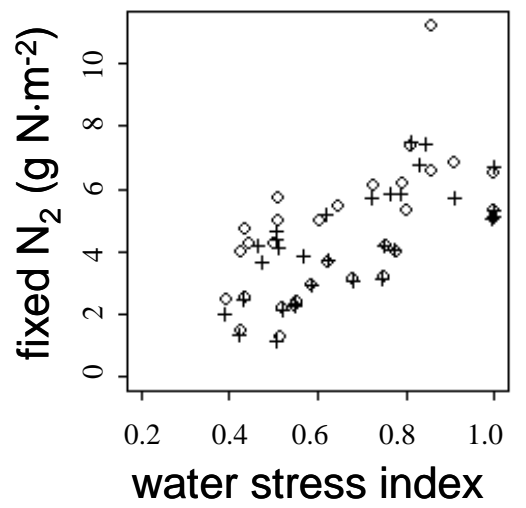

(d)

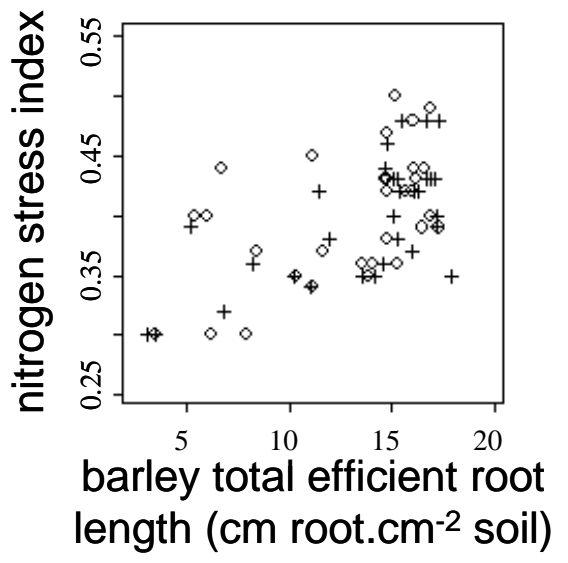

(f)
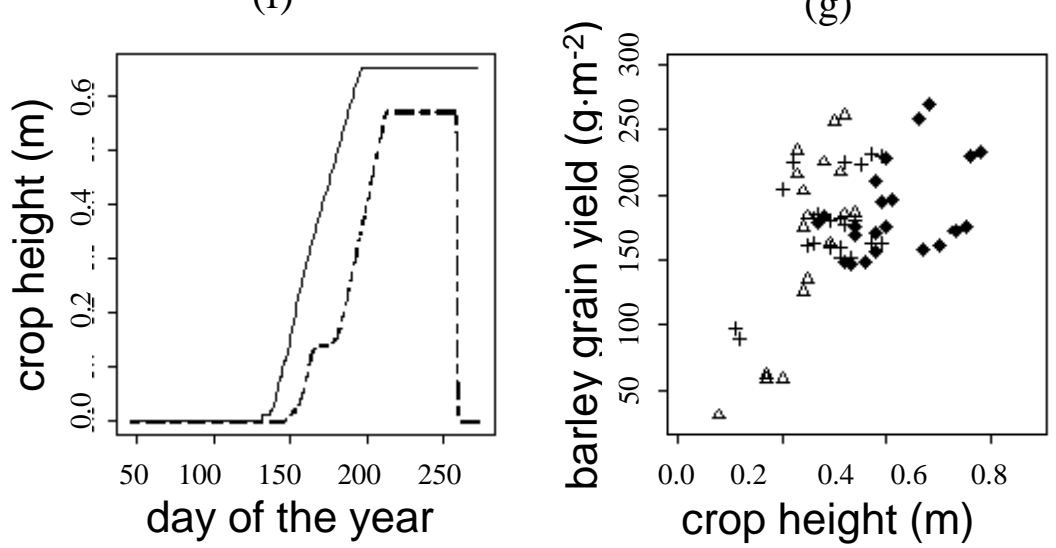

Figure 6 


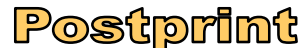

Version définitive du manuscrit publié dans / Final version of the manuscript published in : European Journal of Agronomy, 2009, vol.31, no.2, 85-98, DOI: 10.1016/j.eja.2009.04.002
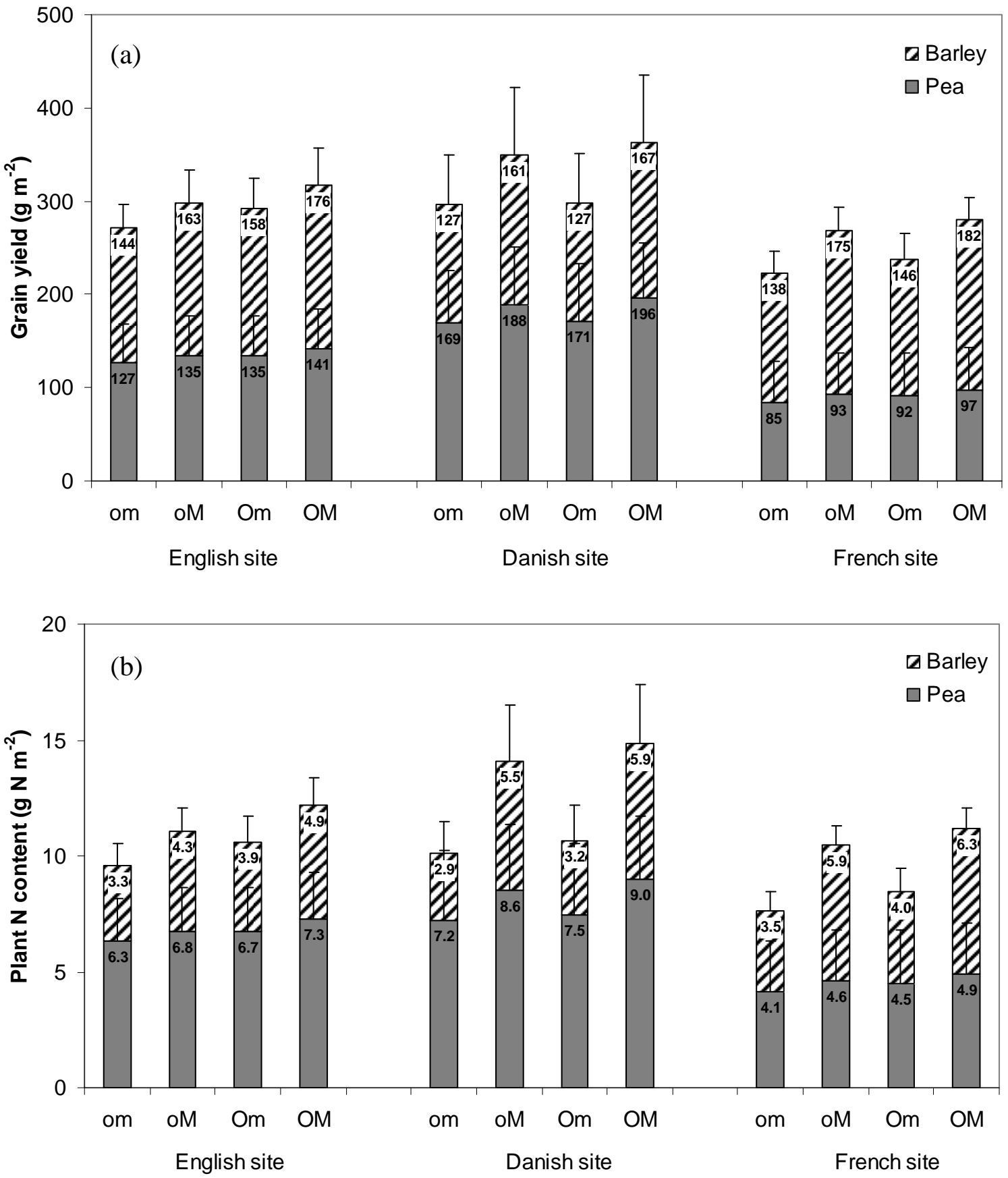

Figure 7 


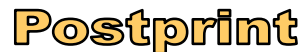

Version définitive du manuscrit publié dans / Final version of the manuscript published in : European Journal of Agronomy, 2009, vol.31, no.2, 85-98, DOI: 10.1016/j.eja.2009.04.002

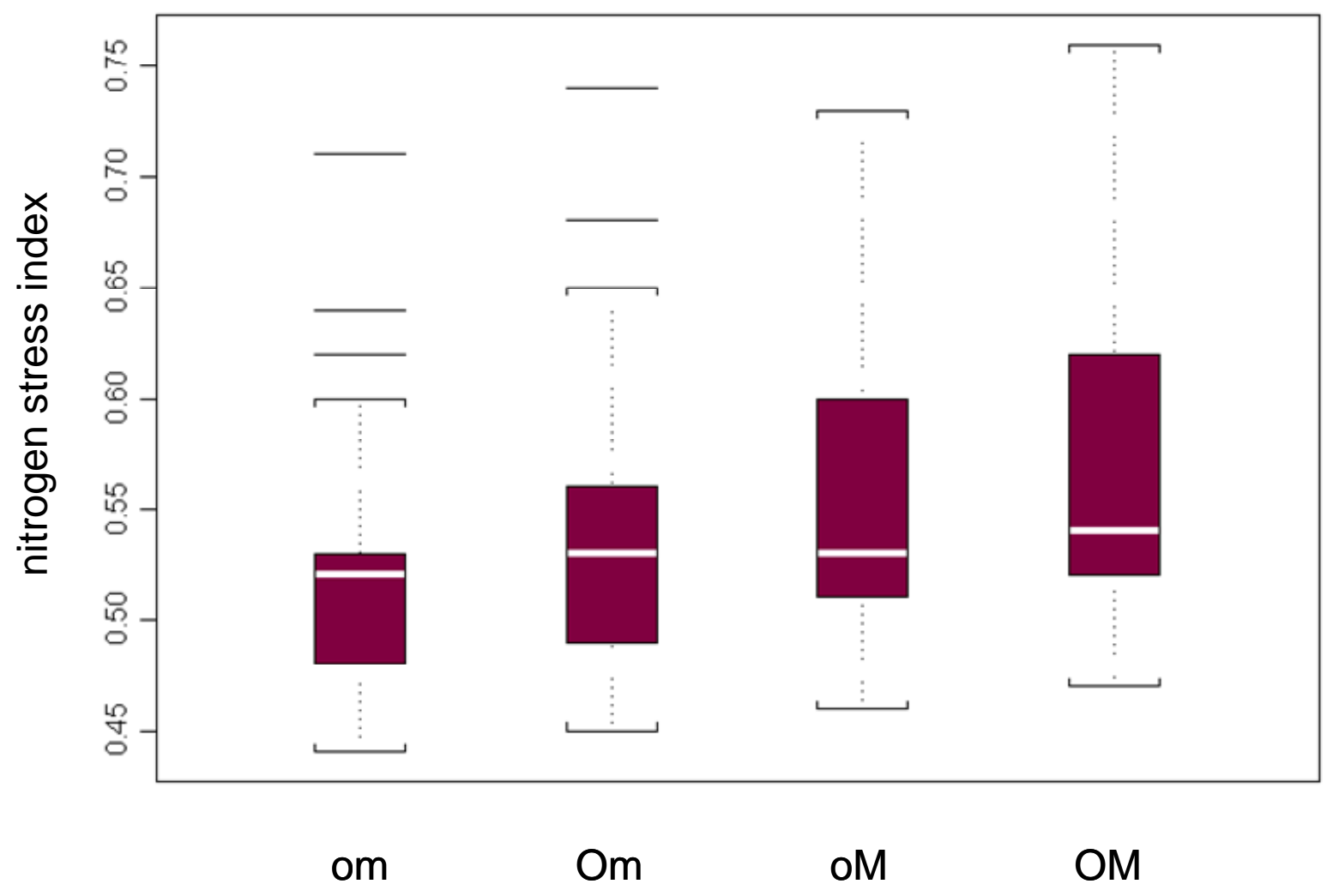

Figure 8

Comment citer ce document 